\title{
Microalgae Cultivation Technologies as an Opportunity for Bioenergetic System Development-Advantages and Limitations
}

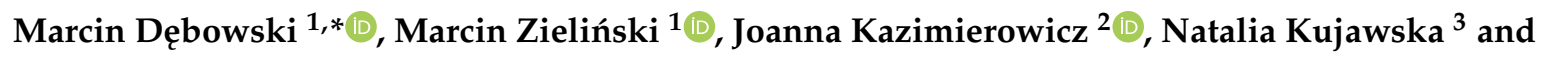 \\ Szymon Talbierz ${ }^{3}$ \\ 1 Department of Environmental Engineering, Faculty of Geoengineering, University of Warmia and \\ Mazury in Olsztyn, 10-720 Olsztyn, Poland; marcin.zielinski@uwm.edu.pl \\ 2 Department of Water Supply and Sewage Systems, Faculty of Civil Engineering and Environmental Sciences, \\ Bialystok University of Technology, 15-351 Białystok, Poland; j.kazimierowicz@pb.edu.pl \\ 3 InnovaTree Sp. z o.o., 81-451 Gdynia, Poland; natalia.kujawska@innovatree.pl (N.K.); \\ szymon.talbierz@innovatree.pl (S.T.) \\ * Correspondence: marcin.debowski@uwm.edu.pl
}

Received: 19 September 2020; Accepted: 27 November 2020; Published: 29 November 2020

\begin{abstract}
Microalgal biomass is currently considered as a sustainable and renewable feedstock for biofuel production (biohydrogen, biomethane, biodiesel) characterized by lower emissions of hazardous air pollutants than fossil fuels. Photobioreactors for microalgae growth can be exploited using many industrial and domestic wastes. It allows locating the commercial microalgal systems in areas that cannot be employed for agricultural purposes, i.e., near heating or wastewater treatment plants and other industrial facilities producing carbon dioxide and organic and nutrient compounds. Despite their high potential, the large-scale algal biomass production technologies are not popular because the systems for biomass production, separation, drainage, and conversion into energy carriers are difficult to explicitly assess and balance, considering the ecological and economical concerns. Most of the studies presented in the literature have been carried out on a small, laboratory scale. This significantly limits the possibility of obtaining reliable data for a comprehensive assessment of the efficiency of such solutions. Therefore, there is a need to verify the results in pilot-scale and the full technical-scale studies. This study summarizes the strengths and weaknesses of microalgal biomass production technologies for bioenergetic applications.
\end{abstract}

Keywords: microalgal biomass; microalgae cultivation; biofuels; advantages; limitations

\section{Introduction}

Microalgae are single-cell organisms that convert solar radiation energy into chemical energy via photosynthesis [1]. Controlled production of microalgal biomass is a fast-growing technology, as microalgae can be used to produce a wide range of commercially valuable cellular metabolites, including high-quality proteins, lipids, carbohydrates, dyes, and vitamins for the food/feed industry and the broad cosmetic industry (Table 1).

The fact that microalgae represent an alternative and competitive source of biomass is due to their advantage over typical terrestrial and energy plants [2]. Algae possess very high photosynthetic efficiency [3], can relatively fast build biomass [4], are resistant to various contaminants [5], and can be grown on land that is unsuitable for other purposes [6]. Microalgae production systems can also be used in environment-protecting technologies [7], including sewage and leachate treatment [8], neutralization of waste and sludge [9], carbon dioxide biosequestration, biogas upgrading, and flue gas treatment [10] (Table 2). This makes it possible to select and adapt specific strains for individual 
applications, including energy carrier production, environmental protection, and environmental engineering technologies [11]. Given these considerations, algae may provide a viable alternative to traditional energy crops [12].

Table 1. Venues for microalgal biomass application.

\begin{tabular}{|c|c|c|c|}
\hline & Product & Use & Ref. \\
\hline & Agar & $\begin{array}{l}\text { Food ingredient, fruit preserves, hydrocolloids, clarifying } \\
\text { brewing agent, paper industry, and others }\end{array}$ & [13] \\
\hline & Alginate & $\begin{array}{l}\text { Food additive, medical, pharmaceutical, paper, cosmetic and } \\
\text { fertilizer industries, textile printing }\end{array}$ & {$[1]$} \\
\hline & Antioxidants & $\begin{array}{l}\text { Preservatives in cosmetic, chemical, food, } \\
\text { and pharmaceutical industries }\end{array}$ & [14] \\
\hline & Astaxanthin & Food supplement as food dye additive and antioxidant & [15] \\
\hline Beta-car & otene and carotenoids & $\begin{array}{l}\text { Precursor for vitamin A and supplement for vitamin } C \text {, food } \\
\text { additive as coloring agent, and antioxidant }\end{array}$ & [16] \\
\hline Bioe & nergy and biofuels & $\begin{array}{c}\text { Biodiesel, bioethanol, biogas, biohydrogen, biomethane, } \\
\text { aviation gas, biobutanol, biosyngas, bio-oil, gasoline, solid } \\
\text { fuel, jet fuel }\end{array}$ & [15] \\
\hline & Biochar & Agricultural and sorbent uses, combustion & [13] \\
\hline & Biorefinery & Various chemicals and biofuels & [14] \\
\hline & Biosorbents & Ion exchange materials that bind strongly heavy metal ions & [1] \\
\hline Carra & gen or carrageenan & Pet food, food additive, gels, toothpaste & {$[1]$} \\
\hline & Catalysts & Catalytic properties & [14] \\
\hline & Chemicals & Industrial and medicinal uses & [1] \\
\hline & Conditioners & Chemical, cosmetic, and farming industries & [15] \\
\hline & igester residue & Compost or vermicompost & [13] \\
\hline \multirow{4}{*}{$\begin{array}{l}\text { Extraction } \\
\quad \text { of }\end{array}$} & hydrocolloids or gums & $\begin{array}{l}\text { Food industry, phytocolloids such as agar, alginate, } \\
\text { and carrageenan }\end{array}$ & \multirow{4}{*}{14} \\
\hline & $\begin{array}{l}\text { lipids carbohydrates } \\
\text { starch and cellulose }\end{array}$ & $\begin{array}{c}\text { Biogas, biodiesel, gasoline, jet fuel, alcohols, renewable } \\
\text { hydrocarbons }\end{array}$ & \\
\hline & $\begin{array}{l}\text { minerals and trace } \\
\text { elements }\end{array}$ & Food supplements, glass production, metallurgy & \\
\hline & proteins & $\begin{array}{l}\text { Fertilizers, industrial enzymes, animal/fish feeds, } \\
\text { surfactants, bioplastics }\end{array}$ & \\
\hline & Feed & Animal food & [15] \\
\hline & Fertilizers & $\mathrm{N}-, \mathrm{P}-$, and K-rich fertilizers & [1] \\
\hline & Phytosterol & Food supplements & [15] \\
\hline & Pigments & Natural colorants in paper and textile industries & [14] \\
\hline \multirow{7}{*}{ Production } & Cosmetic & Water-binding agents and antioxidants, "skin foods" & \multirow{7}{*}{ [15] } \\
\hline & Food and drink & $\begin{array}{l}\text { Nori, kombu, wakame, cheese, soup, noodles, pasta, wine, } \\
\text { tea, others }\end{array}$ & \\
\hline & $\begin{array}{l}\text { Fruit and vegetable } \\
\text { preservatives }\end{array}$ & Food industry & \\
\hline & Glass & Glass industry & \\
\hline & Paper pulp supplements & Paper industry & \\
\hline & Textile & Textile industry & \\
\hline & Therapeutic materials & Pharmaceutical industry & \\
\hline
\end{tabular}


Table 2. Applications of microalgae in environment-protecting technologies.

\begin{tabular}{|c|c|c|c|}
\hline Sector & & Use & Ref. \\
\hline \multirow{8}{*}{$\begin{array}{l}\text { Wastewater } \\
\text { treatment }\end{array}$} & \multicolumn{2}{|c|}{ Nitrogen and phosphorus removal from municipal wastewater } & [17] \\
\hline & \multicolumn{2}{|c|}{ Biodegradation of sparingly degradable pollutants } & {$[18,19]$} \\
\hline & \multicolumn{2}{|c|}{ Treatment of organic wastewater } & {$[20]$} \\
\hline & \multirow{3}{*}{$\begin{array}{l}\text { Treatment of hard-to-manage } \\
\text { wastewater produced by }\end{array}$} & timber and paper industry & {$[21,22]$} \\
\hline & & textile industry & {$[23]$} \\
\hline & & phenol industry & {$[24,25]$} \\
\hline & \multicolumn{2}{|c|}{ Ethanol and citric acid production } & [26] \\
\hline & \multicolumn{2}{|c|}{ Removal of heavy metals (copper, nickel, lead) from wastewater } & {$[19,27]$} \\
\hline Gas treatment & $\begin{array}{r}\text { Reducing emissions of carbon di } \\
\text { oxides) fron }\end{array}$ & $\begin{array}{l}\text { de and other pollutants (nitrogen and sulfur } \\
\text { aste and exhaust gases }\end{array}$ & {$[28,29]$} \\
\hline \multirow{5}{*}{$\begin{array}{l}\text { Waste } \\
\text { management }\end{array}$} & Use of waste glycerol as a c & on source in heterotrophic cultivation & [30] \\
\hline & \multirow{4}{*}{$\begin{array}{l}\text { Microalgae cultivation using } \\
\text { industrial waste or low-value } \\
\text { feedstocks, such as }\end{array}$} & breadcrumbs & [31] \\
\hline & & brewer's spent yeast & [32] \\
\hline & & coconut water & [33] \\
\hline & & empty palm fruit bunches & [34] \\
\hline \multirow{2}{*}{$\begin{array}{l}\text { Leachate } \\
\text { treatment }\end{array}$} & \multicolumn{2}{|c|}{ Biodegradation of landfill leachates } & [35] \\
\hline & \multicolumn{2}{|c|}{ Neutralization of degraded effluent from anaerobic fermentation of sewage sludge } & [36] \\
\hline $\begin{array}{c}\text { Biogas } \\
\text { upgrading }\end{array}$ & \multicolumn{2}{|c|}{$\begin{array}{l}\text { Biological sequestration of } \mathrm{CO}_{2} \text { with photosynthetic microalgae (photosynthesis } \\
\text { allows producing biogas with } 94 \% \text { methane content) }\end{array}$} & [37] \\
\hline
\end{tabular}

However, the most promising frontiers for microalgae concern their utility for energy purposes, including the production of biogas, biohydrogen, bioethanol, and biodiesel [38]. Microalgal biomass is undoubtedly a promising substrate for energy carrier production, characterized by lower pollutant emission levels compared to conventional fuels $[39,40]$. By way of example, forecasts for the United States (US) biofuel and biodiesel market [41,42] are shown in Figure 1.

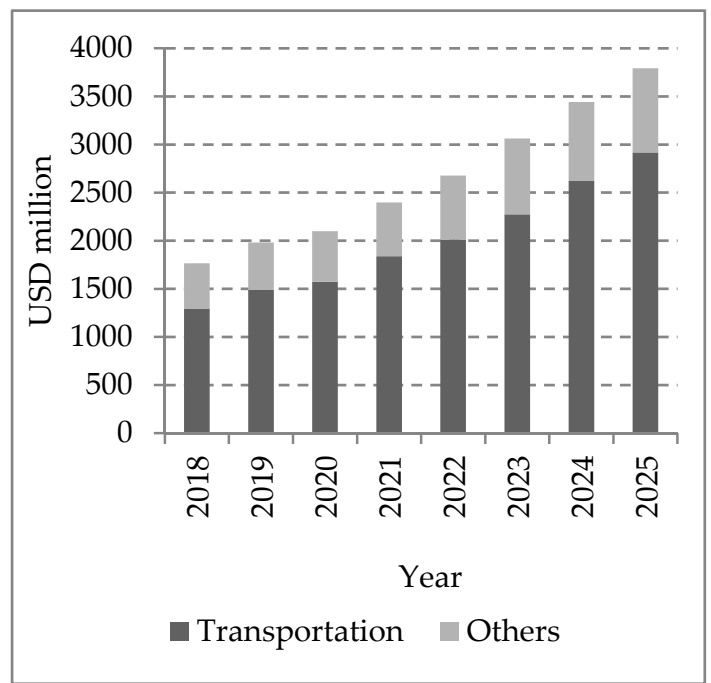

(a)

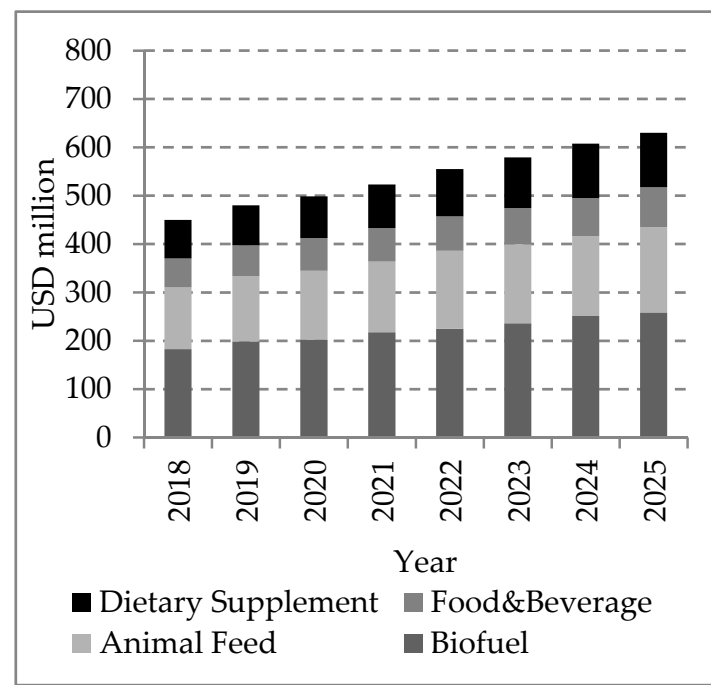

(b)

Figure 1. Growth forecasts for the United States of America (USA) algae-based biofuel market by 2025 ((a)—algae biofuel market, (b)—algae oil market). 
Systems for producing algal biomass feature high technological efficiency, owing to the significant photosynthesis efficiency of algae and the relatively fast growth of algal biomass [43]. Phototrophic cultivation of microalgae in photobioreactors can process waste from industrial and municipal sources, which means that commercial microalgae cultivation systems can be constructed on land unsuitable for agricultural use, near heating/cogeneration plants, sewage treatment plants, and other industrial facilities that produce carbon dioxide and biogenic compounds [44].

Despite the demonstrated utility of microalgal biomass-based systems for the bioenergy industry, most industrial microalgae cultivation plants established and extensively described in the literature deal mainly with the production of high-quality feed/food additives, precious dyes, or fertilizing substances (Table 1), due to the difficulties in conclusively assessing and balancing methods for microalgal biomass production and technologies for converting it to energy carriers [45]. The majority of studies were carried out in laboratory conditions, with semi-industrial (pilot-scale) projects being a rarity [46]. The few examples of small-scale bioreactors are presented in Table 3 and pilot installations in Table 4.

The commercialization of technology and its transfer from laboratory conditions to a technical scale requires extensive research, conceptual, operational, and marketing works that allow the product to be finally placed on the market. Although relative studies present various models of knowledge and technology commercialization, they also show some similarities, as they involve a certain repetitive group of activities [47]. An important element in the process of making investment decisions regarding the commercialization of innovative products is to assess the maturity of new technologies. This assessment, called "technology readiness assessment" (TRA), should take into account the state of work on the development of a new product/technology, prospects for further development, the amount of funds necessary to invest, and innovative risk. It is a universal metric used to analyze the state of work on technologies and their readiness for commercial implementation. In turn, the "technology readiness level" (TRL) methodology sets nine levels of technology readiness and allows assessing the progress of works on new technologies [48]. It was first used in research and development (R\&D) projects carried out by the National Aeronautics and Space Administration (NASA) and the US defense industry. According to TRL, technology maturity is described from the conceptualization phase of a specific solution (TRL 1) to the maturity stage (TRL 9), when this concept (as a result of research and development works) takes the form of a technological solution that can be implemented in practice, e.g., by launching production and marketing [49].

Table 3. Comparison of the efficiency of lab-scale microalgae cultivation systems; n.a., not applicable.

\begin{tabular}{|c|c|c|c|c|c|}
\hline $\begin{array}{c}\text { Microalgal } \\
\text { Strains/Biomass }\end{array}$ & $\begin{array}{l}\text { Cultivation } \\
\text { System and } \\
\text { Operation } \\
\text { Mode }\end{array}$ & $\begin{array}{l}\text { Cultivation } \\
\text { Time } \\
\text { (days) }\end{array}$ & $\begin{array}{l}\text { Algal Growth, } \\
\text { in } \mathrm{g} \cdot \mathrm{dm}^{-3} \text { (Dry Basis) } \\
\text { or cells } \cdot \mathrm{cm}^{-3}\end{array}$ & $\begin{array}{c}\text { Biomass } \\
\text { Productivity } \\
\left(\mathrm{mg} \cdot \mathrm{dm}^{-3} \cdot \mathrm{day}^{-1}\right)\end{array}$ & Ref. \\
\hline $\begin{array}{l}\text { Chlamydomonas } \\
\text { sp. SW13aLS }\end{array}$ & $\begin{array}{c}250 \mathrm{~cm}^{3} \text { flask; } \\
\text { batch }\end{array}$ & 30 & No growth & No growth & [50] \\
\hline $\begin{array}{l}\text { Chlorella pyrenoidosa } \\
\text { FACHB-28 }\end{array}$ & $\begin{array}{c}30 \mathrm{dm}^{3} \text { membrane } \\
\text { Define if appropriate.; } \\
\text { batch }\end{array}$ & 30 & $0.41-0.63 \mathrm{~g} \cdot \mathrm{dm}^{-3}$ & $60-80$ & [51] \\
\hline $\begin{array}{l}\text { Chlorella pyrenoidosa } \\
\text { NCIM } 2738\end{array}$ & $\begin{array}{l}3 \mathrm{dm}^{3} \text { tubular } \\
\text { PBR; batch }\end{array}$ & 18 & $2.9 \mathrm{~g} \cdot \mathrm{dm}^{-3}$ & 260 & [52] \\
\hline $\begin{array}{l}\text { Chlorella sp. (isolated } \\
\text { from a clean } \\
\text { lagoon) }\end{array}$ & $\begin{array}{c}500 \mathrm{~cm}^{3} \\
\text { flasks; batch }\end{array}$ & 28 & $3 \times 10^{7}$ cells $\cdot \mathrm{cm}^{-3}$ & n.a. & [53] \\
\hline $\begin{array}{l}\text { Chlorella sp. } \\
\text { (isolated from } \\
\text { leachate) }\end{array}$ & $\begin{array}{c}350 \mathrm{~cm}^{3} \\
\text { flasks; batch }\end{array}$ & 14 & $0.09-0.43 \mathrm{~g} \cdot \mathrm{dm}^{-3}$ & $18-66$ & [54] \\
\hline
\end{tabular}


Table 3. Cont.

\begin{tabular}{|c|c|c|c|c|c|}
\hline $\begin{array}{c}\text { Microalgal } \\
\text { Strains/Biomass }\end{array}$ & $\begin{array}{c}\text { Cultivation } \\
\text { System and } \\
\text { Operation } \\
\text { Mode }\end{array}$ & $\begin{array}{l}\text { Cultivation } \\
\text { Time } \\
\text { (days) }\end{array}$ & $\begin{array}{l}\text { Algal Growth, } \\
\text { in } \mathrm{g} \cdot \mathrm{dm}^{-3} \text { (Dry Basis) } \\
\text { or cells } \cdot \mathrm{cm}^{-3}\end{array}$ & $\begin{array}{c}\text { Biomass } \\
\text { Productivity } \\
\left(\mathrm{mg} \cdot \mathrm{dm}^{-3} \cdot \text { day }^{-1}\right)\end{array}$ & Ref. \\
\hline $\begin{array}{l}\text { Chlorella sp. } \\
\text { (marine) }\end{array}$ & $\begin{array}{l}24 \mathrm{dm}^{3} \text { tubular } \\
\text { PBR; batch }\end{array}$ & 3 & $2.2-2.6 \times 10^{6} \mathrm{cells} \cdot \mathrm{cm}^{-3}$ & n.a. & [55] \\
\hline $\begin{array}{c}\text { Chlorella vulgaris CCAP } \\
211 / 11 \mathrm{~B}\end{array}$ & $\begin{array}{l}1 \mathrm{dm}^{3} \text { flasks; } \\
\text { batch }\end{array}$ & 10 & $0.81-1.71 \mathrm{~g} \cdot \mathrm{dm}^{-3}$ & $20-110$ & [56] \\
\hline $\begin{array}{l}\text { Chlorella vulgaris } \\
\text { CCAP } 211\end{array}$ & $\begin{array}{l}2 \mathrm{dm}^{3} \text { vertical } \\
\text { PBR; batch }\end{array}$ & 28 & $2.10 \mathrm{~g} \cdot \mathrm{dm}^{-3}$ & 63.8 & [57] \\
\hline $\begin{array}{l}\text { Chlorella vulgaris } \\
\text { FACHB-31 }\end{array}$ & $\begin{array}{l}\text { Membrane } \\
\text { PBR with } \\
\text { two } 2 \mathrm{dm}^{3} \\
\text { chambers; } \\
\text { batch }\end{array}$ & 8 & $0.95 \mathrm{~g} \cdot \mathrm{dm}^{-3}$ & 240 & [58] \\
\hline $\begin{array}{l}\text { Chlorella vulgaris } \\
\text { FACHB- } 31\end{array}$ & $\begin{array}{l}2 \mathrm{dm}^{3} \text { tubular } \\
\text { PBR; batch }\end{array}$ & 8 & $0.66 \mathrm{~g} \cdot \mathrm{dm}^{-3}$ & 150 & [58] \\
\hline $\begin{array}{l}\text { Chlorella vulgaris } \\
\text { FACHB-31 }\end{array}$ & $\begin{array}{c}3 \mathrm{dm}^{3} \text { membrane } \\
\text { PBRs; } \\
\text { batch }\end{array}$ & 12 & $2.13 \mathrm{~g} \cdot \mathrm{dm}^{-3}$ & n.a. & [58] \\
\hline $\begin{array}{l}\text { Chlorella vulgaris } \\
\text { FACHB-31 }\end{array}$ & $\begin{array}{l}3 \mathrm{dm}^{3} \text { tubular } \\
\text { PBR; batch }\end{array}$ & 2 & No growth & No growth & [58] \\
\hline $\begin{array}{l}\text { Chlorella vulgaris and } \\
\text { Chlamydomonas } \\
\text { reinhardii }\end{array}$ & $\begin{array}{l}500 \mathrm{~cm}^{3} \text { bottles; } \\
\text { batch }\end{array}$ & $28-60$ & $0.46-1.5 \mathrm{~g} \cdot \mathrm{dm}^{-3}$ & n.a. & [59] \\
\hline $\begin{array}{l}\text { Chlorella vulgaris and } \\
\text { Chlamydomonas } \\
\text { reinhardii }\end{array}$ & $\begin{array}{l}200 \mathrm{dm}^{3} \text { open } \\
\text { raceway } \\
\text { pond; } 5 \\
\text { runs; batch }\end{array}$ & $32-54$ & $0.68-1.03 \mathrm{~g} \cdot \mathrm{dm}^{-3}$ & $160-440$ & [59] \\
\hline $\begin{array}{c}\text { Nannochloropsis } \\
\text { gaditana,Pavlova } \\
\text { lutheri, Tetraselmis } \\
\text { chuii, } \\
\text { and Chetoceros } \\
\text { muelleri }\end{array}$ & $\begin{array}{c}2.5 \text { and } \\
12.5 \mathrm{dm}^{3} \\
\text { cylindrical } \\
\text { PBR; batch }\end{array}$ & 10 & Up to $9 \times 10^{6}$ cells $\cdot \mathrm{cm}^{-3}$ & n.a. & [60] \\
\hline $\begin{array}{l}\text { Oscillatoria sp. } \\
\text { (isolated from } \\
\text { leachate) }\end{array}$ & $\begin{array}{c}350 \mathrm{~cm}^{3} \\
\text { flasks; batch }\end{array}$ & 14 & $0.43-0.81 \mathrm{~g} \cdot \mathrm{dm}^{-3}$ & $44-107$ & [54] \\
\hline $\begin{array}{c}\text { Picochlorum oculatum } \\
\text { UTEX LB } \\
1998\end{array}$ & $\begin{array}{c}150 \mathrm{dm}^{3} \\
\text { horizontal } \\
\text { bioreactor; } \\
\text { fed-batch; } 3 \\
\text { cycles }\end{array}$ & $18-37$ & $\begin{array}{c}1.5-1.9 \mathrm{~g} \cdot \mathrm{dm}^{-3} \\
\left(1.2-1.7 \times 10^{9} \text { cells } \cdot \mathrm{cm}^{-3}\right)\end{array}$ & $37-55$ & [61] \\
\hline $\begin{array}{l}\text { Scenedesmus sp. } \\
\text { (isolated from } \\
\text { leachate) }\end{array}$ & $\begin{array}{c}350 \mathrm{~cm}^{3} \\
\text { flasks; batch }\end{array}$ & 14 & $0.16-0.24 \mathrm{~g} \cdot \mathrm{dm}^{-3}$ & $37-46$ & [54] \\
\hline $\begin{array}{l}\text { Scenedesmus sp. } \\
\text { CHX1 }\end{array}$ & $\begin{array}{c}250 \mathrm{~cm}^{3} \\
\text { flasks; batch }\end{array}$ & 20 & $0.22 \mathrm{~g} \cdot \mathrm{dm}^{-3}$ & 37.5 & [62] \\
\hline
\end{tabular}

As such, there are very few sources of reliable data for a comprehensive evaluation of the technological, environmental, and economic efficiency of these solutions [63]. Such assessments are further complicated because various researchers have presented contradictory conclusions on microalgal biomass productivity, as well as its actual technological performance and cost-effectiveness. Lardon et al. (2009) unfavorably compared microalgal cultivation with traditional production methods, concluding that it is not a financially viable means of biodiesel production due to very high costs of biomass cultivation, harvesting, and drying, as well as of oil extraction [64]. On the other hand, Clarens et al. (2011) demonstrated the opposite, obtaining a positive energy balance and a beneficial environmental outcome for the biodiesel produced from microalgal biomass. They used exhaust gases and wastewater as sources of carbon dioxide and biogenic compounds for the growth medium [65]. In turn, Frank et al. (2011) used computational software to create a model that demonstrated microalgal 
fuel production technologies to be less energy-efficient and producing more greenhouse gases than traditional biofuel production methods [66].

Table 4. Pilot projects concerning microalgal biomass production and its conversion to energy carriers. PUFA, polyunsaturated fatty acid; DHA, docosahexaenoic acid.

\begin{tabular}{|c|c|c|}
\hline Projects/Research Institutes & Focal Area & Ref. \\
\hline $\begin{array}{l}\text { Algae Innovation Center, Green } \\
\text { Centre, Denmark }\end{array}$ & $\begin{array}{l}\text { Demonstration and test projects concerning algae cultivation; an } \\
\text { assessment of biomass viability was conducted on the site (in } \\
\text { Rødsand II) }\end{array}$ & [67] \\
\hline Algenol, USA & $\begin{array}{c}\text { Production of bioethanol and pigments in a raceway pond, } \\
\text { and closed and semi-closed bioreactors }\end{array}$ & [68] \\
\hline Algatechnologies, Israel & $\begin{array}{l}\text { Production of astaxanthin in closed and semi-closed bioreactors } \\
\text { under high light intensity }\end{array}$ & [69] \\
\hline Algenol Biotech, LLC & $\begin{array}{l}\text { An integrated, pilot project involving the photosynthetic } \\
\text { production of ethanol and the delivery of a photobioreactor } \\
\text { system that can be scaled for commercial operation }\end{array}$ & [70] \\
\hline BioReal Inc, USA & Production of astaxanthin in an indoor photobioreactor & [71] \\
\hline BioProcess Algae, LLC & $\begin{array}{l}\text { A pilot project on growing low-cost algae using renewable } \mathrm{CO}_{2} \text {, } \\
\text { lignocellulosic sugars, and waste heat provided by a co-located } \\
\text { ethanol plant }\end{array}$ & [70] \\
\hline $\begin{array}{l}\text { Blue Bio Projekt (IVA } \\
\text { Kattegat-Skagerrak) }\end{array}$ & Finding sustainable ways of exploiting microalgae & [67] \\
\hline Cellana, USA & $\begin{array}{l}\text { Production of PUFAs, animal feed, biodiesel, and bio jet fuel in } \\
\text { an open-pond bioreactor }\end{array}$ & [72] \\
\hline Cyanotech, Hawaii & $\begin{array}{l}\text { Production of astaxanthin from Spirulina pacifica as a food } \\
\text { ingredient in a raceway pond and photobioreactors }\end{array}$ & [69] \\
\hline IGV Gmbh, Germany & Algae cultivation in a photobioreactor & [67] \\
\hline Kingfisher, Sweden & $\begin{array}{l}\text { Tested equipment (including offshore wind parks) for offshore } \\
\text { mussel and algae cultivation }\end{array}$ & [67] \\
\hline $\begin{array}{l}\text { Mera Pharmaceuticals } \\
\text { Incorporation }\end{array}$ & $\begin{array}{l}\text { Production of astaxanthin from Haematococcus pluvialis in a } \\
\text { raceway pond }\end{array}$ & [73] \\
\hline Muradel Pty Ltd., Australia & $\begin{array}{c}\text { Production of biofuels, oleochemicals, biofertilizers, animal feed, } \\
\text { and building materials in a raceway pond }\end{array}$ & [74] \\
\hline Sea6 Energy, India & $\begin{array}{c}\text { Production of food additives, biofuel, bioplastic, and animal } \\
\text { feed in sea water }\end{array}$ & [75] \\
\hline Sapphire Energy Inc. USA & $\begin{array}{l}\text { A demonstration-scale project involving the construction and } \\
\text { operation of a 100-acre algae farm and conversation facility for } \\
\text { the production of renewable bio-crude }\end{array}$ & [70] \\
\hline Solazyme Inc. USA & $\begin{array}{l}\text { An integrated pilot project involving heterotrophic algae that } \\
\text { can convert cellulosic sugars to diesel fuel }\end{array}$ & [70] \\
\hline Solix Algadrients Inc., USA & $\begin{array}{c}\text { Production of astaxanthin and DHA in enclosed } \\
\text { photobioreactors }\end{array}$ & [76] \\
\hline RWE Power AG, Germany & Flue gas used to grow algae in a demonstration project & [67] \\
\hline $\begin{array}{l}\text { Technical Research Centre of } \\
\text { Finland }\end{array}$ & $\begin{array}{l}\text { Design and validation of a new integrated "biowaste-to-energy" } \\
\text { concept involving algae cultivation and biogas production }\end{array}$ & [67] \\
\hline $\begin{array}{l}\text { University of Warmia and } \\
\text { Mazury in Olsztyn, Poland }\end{array}$ & $\begin{array}{l}\text { Cultivation of lipid-rich microalgal biomass as anaerobic } \\
\text { digestate valorization technology - a pilot-scale study }\end{array}$ & [77] \\
\hline
\end{tabular}

It bears repeating that the research conducted to date was either small-scale or limited to theoretical analyses based on literature data. While these kinds of studies can yield interesting results, they do not provide enough information to properly and exhaustively analyze how such systems perform in operation. Therefore, there is a legitimate need to verify the results obtained in laboratory conditions by launching and operating pilot-scale and full-scale installations. The present paper draws on currently available data to summarize the strengths and weaknesses of biofuel production technologies based on microalgal biomass cultivation. 


\section{Microalgal Biomass as a Source of Biofuels}

Microalgae can serve as a potential source of many different types of biofuels (Figure 2). Examples include anaerobic digestion of biomass into biogas, production of biodiesel from lipids stored in algae cells and hydrogen from photobiological conversion, and lastly, gasification, pyrolysis, or direct combustion of the harvested algal biomass $[78,79]$.

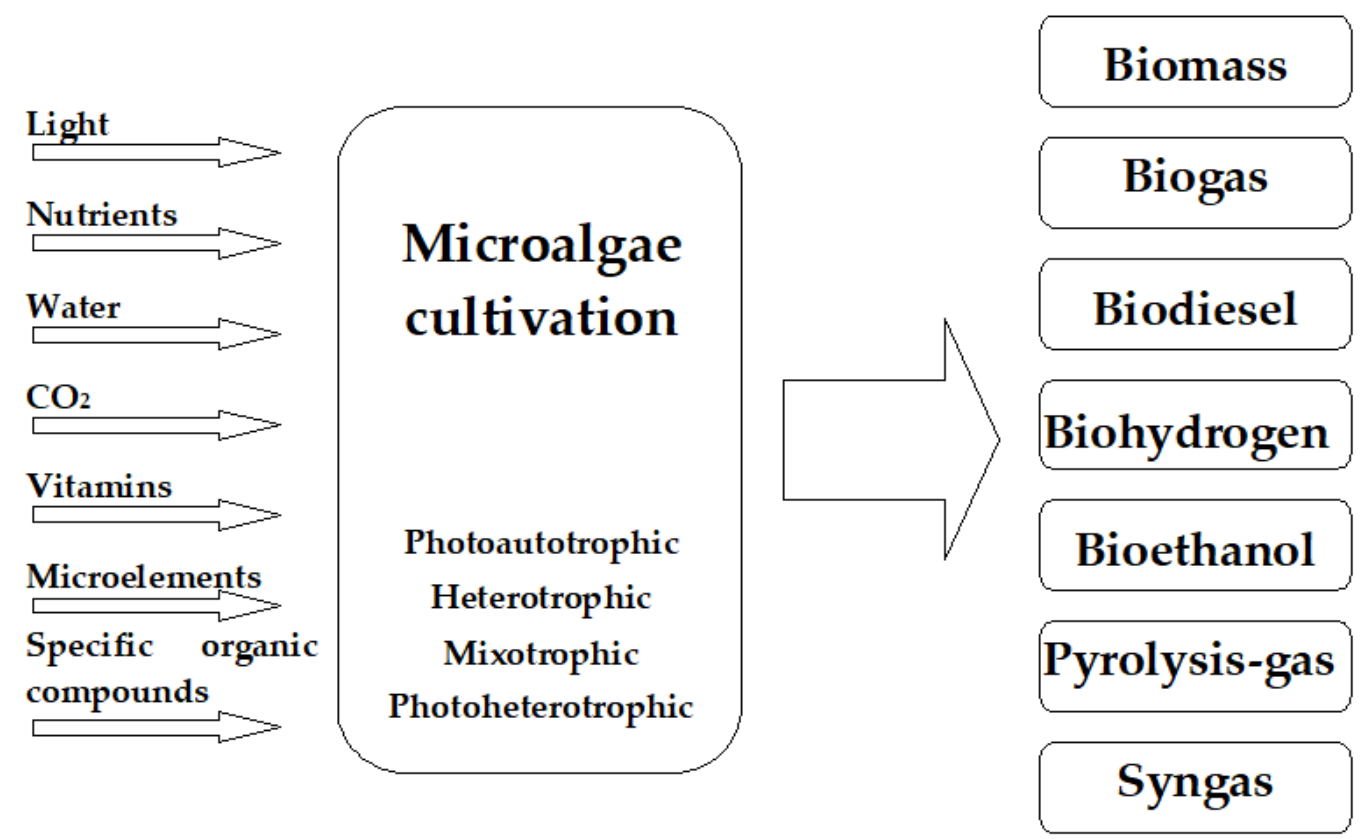

Figure 2. Available mechanisms for producing biofuel with microalgae.

The simplest way to use microalgae for fuel purposes involves the combustion or co-combustion of their pre-dried biomass [80]. However, this solution is rarely practiced, most often in cases where the biomass of microalgae cannot be used to produce more advanced biofuels [81]. Biogas and biomethane are produced during controlled, anaerobic degradation of microalgal biomass by fermentation bacteria [82]. Methane fermentation is a cascade of successive biochemical transformations, including hydrolysis, acidogenesis, and methanogenesis, which are carried out by specialized consortia of microorganisms [83]. In turn, biodiesel is produced via the transesterification of bio-oil extracted from microalgal biomass. This process involves the reaction of triglyceride molecules, bio-oil components, with low-molecular-weight alcohols in the presence of catalysts [84]. Hydrogen production by microalgae is based on direct biophotolysis, which involves the photosynthetic production of hydrogen from water, which uses the energy of light to break down the water molecule into hydrogen and oxygen. The process is mediated by hydrogenase-a metal enzyme that catalyzes the reversible oxidation of $\mathrm{H}_{2}$ and releases gaseous hydrogen by reducing protons [85]. The basic technology for bioethanol production from microalgae entails a biochemical process in which bacteria hydrolyze the biomass and then yeast convert the sugars present in the biomass into alcohol, which is then distilled and dehydrated [86]. In turn, syngas and pyrolytic gas are produced via the endothermal conversion of biomass into gas, which mainly consists of hydrogen, carbon monoxide, carbon dioxide, methane, and low-molecular-weight hydrocarbons [87]. The contribution of individual products, including their qualitative composition, depends mainly on the process conditions, such as temperature, reaction time, pressure, and biomass characteristics [88].

The research conducted so far has shown that some microalgae strains have the ability to store substantial quantities of lipids in their cells, with lipid content accounting for even as much as $20-50 \%$ of dry matter (Table 5). 
Table 5. Production of bio-oil from microalgal biomass. DM, dry matter.

\begin{tabular}{|c|c|c|c|c|}
\hline Microalgal Strains/Biomass & $\begin{array}{l}\text { Type of } \\
\text { Culture }\end{array}$ & $\begin{array}{c}\text { Biomass Yield } \\
\left(\mathrm{g}_{\mathrm{DM}} \cdot \mathrm{dm}^{-3} \cdot \mathrm{day}^{-1}\right)\end{array}$ & $\begin{array}{c}\text { Lipid Yield } \\
\left(\mathrm{mg} \cdot \mathrm{dm}^{-3} \cdot \mathrm{day}^{-1}\right)\end{array}$ & Ref. \\
\hline Asteromonas gracilis & Phototrophic & 0.04 & 8.25 & [89] \\
\hline Botryosphaerella sp. AVFF007 (floating cells) & Phototrophic & 0.16 & 46 & {$[90]$} \\
\hline Chaetoceros muelleri F\&M-M43 & Phototrophic & 0.07 & 21.8 & [91] \\
\hline Chlamydomonas sp. YQJ-1 & Phototrophic & 0.06 & 20 & [92] \\
\hline Chlamydomonas reinhardtii & Phototrophic & 0.05 & 10 & [93] \\
\hline Chlorella emersonii & Phototrophic & 0.29 & 55 & [93] \\
\hline Chlorella minutissima UTEX 2341 & Phototrophic & $0.02-0.03$ & $9.0-10.2$ & [94] \\
\hline Chlorella protothecoides & Heterotrophic & $4.0-4.4$ & $1881.3-1840.0$ & [95] \\
\hline Chlorella protothecoides & Heterotrophic & 2 & 932 & [96] \\
\hline Chlorella vulgaris \#259 & Mixotrophic & $0.09-0.25$ & $22.0-54.0$ & [97] \\
\hline Chlorella vulgaris CCAP 211/11B & Phototrophic & 0.17 & 32.6 & [91] \\
\hline Desmodesmus sp. DZL-4 & Phototrophic & 0.16 & 50 & [92] \\
\hline Dunaliella salina & Phototrophic & 0.05 & 10 & [93] \\
\hline Micractinium sp. IR-4 & Phototrophic & 0.11 & 20 & {$[92]$} \\
\hline Monoraphidium sp. QLY-1 & Phototrophic & 0.02 & 11.6 & [98] \\
\hline Monoraphidium sp. QLZ-3 & Phototrophic & 0.03 & 7.2 & [98] \\
\hline Monoraphidium sp. YLY-2 & Phototrophic & 0.01 & 4.9 & [98] \\
\hline Nannochloropsis sp. F\&M-M29 & Phototrophic & 0.17 & 37.6 & [91] \\
\hline Pavlova salina CS 49 & Phototrophic & 0.16 & 49.4 & [91] \\
\hline Phaeodactylum tricornutum F\&M-M40 & Phototrophic & 0.24 & 44.8 & [91] \\
\hline Scenedesmus obliquus & Mixotrophic & $0.10-0.51$ & $11.6-58.6$ & [99] \\
\hline Scenedesmus obliquus & Phototrophic & 0.06 & 7.14 & [99] \\
\hline Scenedesmus quadricauda & Phototrophic & 0.19 & 35.1 & [91] \\
\hline Scenedesmus sp. DM & Phototrophic & 0.26 & 53.9 & [91] \\
\hline Scenedesmus sp. F\&M-M19 & Phototrophic & 0.21 & 40.8 & [91] \\
\hline Schizochytrium sp. S31 & Phototrophic & 0.88 & 100.7 & [100] \\
\hline Selenastrum sp. XL-3-3 & & 0.22 & 130 & [92] \\
\hline Skeletonema costatum CS 181 & Phototrophic & 0.08 & 17.4 & [91] \\
\hline Tetraselmis suecica F\&M-M33 & Phototrophic & 0.32 & 27 & [91] \\
\hline Thalassiosira pseudonana CS 173 & Phototrophic & 0.08 & 17.4 & [91] \\
\hline Thalassiosira sp. & Phototrophic & $0.02-0.03$ & 10.4 & [101] \\
\hline Thraustochytrium sp. BM2 & Heterotrophic & 2.13 & 1683 & [102] \\
\hline Thraustochytrium sp. CR01 & Heterotrophic & 2 & 1140 & [103] \\
\hline Thraustochytrium striatum & Heterotrophic & 0.4 & 52 & [104] \\
\hline
\end{tabular}

There are also reports describing technologies that stimulate and increase fatty compound storage through controlling the concentration of nitrogen compounds in the growth medium, adjusting the supply of light energy, regulating the temperature conditions, and changing the $\mathrm{CO}_{2}$ levels $[105,106]$. Essential prerequisites for cost-effective biodiesel production include the development of economically feasible technologies for separation/thickening of algal biomass, as well as oil extraction methods [107]. The temperature of the extraction process is a crucial factor that directly affects the quality and quantity of the resultant oil [108]. At temperatures of $60^{\circ} \mathrm{C}$ and lower, higher triglyceride levels are achieved, and oil losses are reduced. Although the common practice of lipid extraction is mainly based on the use of organic solvents, some alternative and competitive technologies are still being sought. Other independent methods that aid the extraction process include mechanical, chemical, and biological treatments [109]. Despite being simple, environmentally friendly, and cheap, the mechanical methods offer a low lipid recovery efficiency [110]. Thus, intensive research works are in progress on the use of ionic liquids, supercritical fluids, bio-based extractants, and switchable solvents with simultaneous attention paid to reducing the energy consumption of the process by eliminating the energy-intensive drying process and the integration of multiple downstream processing steps [111]. A prospective solution for lipid recovery is offered by hybrid methods, e.g., enzymatic and mechanical/solvent 
extraction [112]. The selection of a suitable method for efficient lipid extraction largely depends on the biology and cell-wall characteristics of microalgae [113].

Technologies for converting algal biomass into energy carriers can be divided into two main groups related to thermochemical and biochemical processing [114,115]. Gasification is one of the thermochemical routes, wherein biomass is partially oxidized at temperatures ranging from 800 to $1000{ }^{\circ} \mathrm{C}$ [116]. This technological solution entails reacting the biomass with oxygen and water vapor, which directly results in the generation of syngas-a mixture of $\mathrm{CO}, \mathrm{H}_{2}, \mathrm{CO}_{2}, \mathrm{~N}$, and $\mathrm{CH}_{4}$ [117]. Syngas has a low calorific value, ranging from 4.0 to $6.0 \mathrm{MJ} \cdot \mathrm{m}^{-3}$, and can be combusted directly or used as a fuel in gas turbines and gas engines [118]. The properties and parameters of the microalgal biomass gasification process have been identified by several researchers. A study by Hirano et al. (1998) examined the gasification of Spirulina sp. algae at temperatures between 850 and $1000{ }^{\circ} \mathrm{C}$ and compared the obtained energy value of syngas with that of methanol. The highest operational performance was achieved with a gasification temperature of $1000^{\circ} \mathrm{C}$ [119]. Minowa and Sawayama (1999) gasified Chlorella vulgaris algae within a novel technological system, producing high-methane biofuel, as well as a fertilizer rich in ammonium nitrogen [120].

A different technology for obtaining liquid biofuel is based on thermochemical liquefaction of algal biomass [121]. The process is conducted at $300-350{ }^{\circ} \mathrm{C}$ and 5.0-20.0 MPa Thermochemical reactions are induced in the presence of hydrogen, which serves as a catalyst [122]. The reactors are complex, both design- and technology-wise, which directly affects the construction and operation costs [123]. Dote et al. (1994) successfully used the featured technology to process Botryococcus braunii algae and obtained an oil yield of $64.0 \%$ dry matter of the algae fed into the reactor. The heating value of the bio-oil was $45.9 \mathrm{MJ} \cdot \mathrm{kg}^{-1}$, with a positive energy balance achieved across the entire process [124]. In a similar experiment with Dunaliella tertiolecta, a bio-oil recovery yield reached $42.0 \%$ dry algal biomass, and the calorific value of the resulting product was $34.9 \mathrm{MJ} \cdot \mathrm{kg}^{-1}$ [125].

Pyrolysis is yet another technology used to convert algal biomass into biofuel (Table 6). Compared with the other methods presented in the literature, it has been widely described as a promising technology that yields very good results, inspiring high hopes for application in full-scale installations [126]. Miao and $\mathrm{Wu}$ (2004a) used pyrolysis to extract oil from heterotrophic cultures of Chlorella prothothecoides microalgae and achieved a bio-oil yield of $57.9 \%$ algal dry matter, with the calorific value of the resultant biofuel averaging $41.0 \mathrm{MJ} \cdot \mathrm{kg}^{-1}$ [127]. By comparison, Miao et al. (2004b) produced bio-oil having a calorific value of $30.0 \mathrm{MJ} \cdot \mathrm{kg}^{-1}$ at a yield of $18.0 \%$ dry Chlorella prothothecoides biomass and $29.0 \mathrm{MJ} \cdot \mathrm{kg}^{-1}$ at a yield of $24.0 \%$ dry Microcystis aeruginosa biomass. The algae were grown in autotrophic conditions [128].

Table 6. Studies on slow pyrolysis of microalgae.

\begin{tabular}{|c|c|c|c|}
\hline \multirow{2}{*}{$\begin{array}{c}\text { Microalgal } \\
\text { Strains/Biomass }\end{array}$} & \multicolumn{2}{|c|}{ Oil Recovery } & \multirow[b]{2}{*}{ Ref. } \\
\hline & $\begin{array}{c}\text { Temperature } \\
\left({ }^{\circ} \mathrm{C}\right)\end{array}$ & $\begin{array}{c}\text { Efficiency } \\
(\%)\end{array}$ & \\
\hline Chlorella & 425 & 35.0 & [129] \\
\hline Chlorella vulgaris & 500 & 49.2 & [130] \\
\hline Chlorella vulgaris & 500 & 41.0 & [131] \\
\hline Chlorella protothecoides & 500 & 55.3 & [132] \\
\hline Chrysophyceae & 450 & 49.4 & [129] \\
\hline Cladophora sp. & 600 & 20.0 & [133] \\
\hline Dunaliella salina & 500 & 55.4 & [130] \\
\hline Lyngbya sp. & 600 & 13.0 & [133] \\
\hline Microcystis sp. & 500 & 54.97 & [134] \\
\hline Spirulina & 425 & 40.6 & [129] \\
\hline Spirulina platensis & $350-500$ & $23.0-29.0$ & [135] \\
\hline
\end{tabular}


Demirbas (2006) experimented with the pyrolysis of Chlorella prothotecoides algae, aiming to ascertain how the efficiency of the process changed with temperature. The efficiency of oil recovery from pyrolyzed algal dry matter increased from $5.7 \%$ to $55.3 \%$ as the temperature rose from 254 to $502{ }^{\circ} \mathrm{C}$. Further increases in temperature led to a direct reduction in production yields. The heating value of the harvested bio-oil peaked at $39.7 \mathrm{MJ} \cdot \mathrm{kg}^{-1}$ [136]. Many of the findings published in the literature seem to indicate that bio-oil extracted from algal biomass is higher in quality than the biofuel obtained through pyrolysis of lignocellulosic plants $[136,137]$.

Algae can also serve as a source of ethyl alcohol (Table 7). It has been demonstrated that Chlorella sp. algae are viable candidates for effective alcoholic fermentation due to their high starch content (approximately 37.0\% dry matter). Experimental data indicate a carbohydrate-to-ethanol conversion rate of $65.0 \%$ [138]. Ueno et al. (1998) corroborated the feasibility of ethanol production using microalgae harvested from a heterotrophic culture. The productivity of the alcoholic fermentation process performed at $30^{\circ} \mathrm{C}$ was $450 \mu \mathrm{mol} \cdot \mathrm{g}^{-1}$ dry matter [139]. The research carried out to date confirms that the production of ethyl alcohol from algal biomass can be technologically and commercially viable under specific conditions. In most cases, however, alcoholic fermentation is used as a supplemental technological step for processing algal biomass residues from the oil extraction process [140]. 
Table 7. Ethanol yields from microalgae using different fermentative microorganisms.

\begin{tabular}{|c|c|c|c|c|c|c|c|c|c|c|}
\hline \multirow{2}{*}{$\begin{array}{c}\text { Microalgal } \\
\text { Strains/Biomass }\end{array}$} & \multirow{2}{*}{ Pretreatment } & \multirow{2}{*}{$\begin{array}{l}\text { Fermentative } \\
\text { Microorganism }\end{array}$} & \multicolumn{5}{|c|}{ Fermentation Condition } & \multicolumn{2}{|c|}{ Ethanol Production } & \multirow{2}{*}{ Ref. } \\
\hline & & & 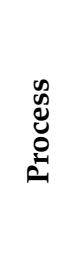 & 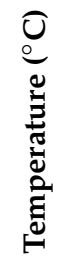 & $\stackrel{\mathscr{\Xi}}{\Xi}$ & $\frac{\pi}{2}$ & 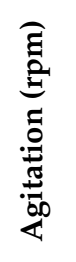 & Max & Units & \\
\hline $\begin{array}{c}\text { Chlamydomonas reinhardtii } \\
\text { UTEX } 90\end{array}$ & Enzymatic & $\begin{array}{c}\text { Saccharomycescerevisiae } \\
\text { S288C }\end{array}$ & SSF & 30 & $40(\mathrm{~h})$ & - & 160 & 0.235 & $\left(\mathrm{~g} \cdot \mathrm{g}^{-1}\right.$ algae $)$ & [141] \\
\hline Chlorella & $\begin{array}{l}\text { Chemical }(\mathrm{HCI} \\
\left.\text { and } \mathrm{MgCI}_{2}\right)\end{array}$ & $\begin{array}{c}\text { Saccharomycescerevisiae } \\
\text { Y01 }\end{array}$ & - & 30 & $48(h)$ & - & 200 & 22.60 & $\left(\mathrm{~g} \cdot \mathrm{dm}^{-3}\right)$ & [142] \\
\hline Chlorella variabilis & $\begin{array}{l}\text { Viral and } \\
\text { enzymatic }\end{array}$ & $\begin{array}{c}\text { Escherichiacoli } \\
\text { KO11 }\end{array}$ & - & 35 & 3 (days) & 6.5 & 150 & 0.326 & $\begin{array}{l}\left(\mathrm{g} \cdot \mathrm{g}^{-1} \text { carbohydrate }\right. \\
\text { consumed) }\end{array}$ & [143] \\
\hline Chlorella vulgaris & Chemical $\left(\mathrm{H}_{2} \mathrm{SO}_{4}\right)$ & $\begin{array}{l}\text { Escherichiacoli } \\
\text { SJL2526 }\end{array}$ & SHF & 37 & - & 7.0 & 170 & 0.4 & $\left(\mathrm{~g} \cdot \mathrm{g}^{-1}\right.$ algae $)$ & [144] \\
\hline $\begin{array}{c}\text { Chlorella vulgaris } \\
\text { FSP-E }\end{array}$ & Chemical $\left(\mathrm{H}_{2} \mathrm{SO}_{4}\right)$ & $\begin{array}{c}\text { Zymomonasmobilis } \\
\text { ATCC } 29191\end{array}$ & SHF & 30 & $12(h)$ & $5-6$ & & 11.66 & $\left(\mathrm{~g} \cdot \mathrm{dm}^{-3}\right)$ & [145] \\
\hline Chlorococcum infusionum & Chemical $(\mathrm{NaOH})$ & Saccharomycescerevisiae & - & 72 & & - & 200 & 0.26 & $\left(\mathrm{~g} \cdot \mathrm{g}^{-1}\right.$ algae $)$ & [146] \\
\hline $\begin{array}{c}\text { Chlorococum } \\
\text { sp. }\end{array}$ & Supercritical fluid & Saccharomycesbayanus & - & 30 & $60(\mathrm{~h})$ & - & 200 & 3.83 & $\left(\mathrm{~g} \cdot \mathrm{dm}^{-3}\right)$ & [147] \\
\hline Porphyridium cruemtum & Enzymatic & $\begin{array}{c}\text { Saccharomycescerevisiae } \\
\text { KCTC } 7906\end{array}$ & SSF & 37 & $9(\mathrm{~h})$ & 4.8 & - & $\begin{array}{l}2.77 \\
2.98\end{array}$ & $\begin{array}{c}\left(\mathrm{g} \cdot \mathrm{dm}^{-3}\right) \text { (seawater) } \\
\left(\mathrm{g} \cdot \mathrm{dm}^{-3}\right) \text { (freshwater) }\end{array}$ & [148] \\
\hline $\begin{array}{l}\text { Scenedesmus obliquus } \\
\text { CNW-N }\end{array}$ & Chemical $\left(\mathrm{H}_{2} \mathrm{SO}_{4}\right)$ & $\begin{array}{c}\text { Zymomonasmobilis } \\
\text { ATCC29191 }\end{array}$ & SHF & 30 & $4(\mathrm{~h})$ & 6 & - & 8.55 & $\left(\mathrm{~g} \cdot \mathrm{dm}^{-3}\right)$ & [145] \\
\hline
\end{tabular}

SSF-simultaneous saccharification and fermentation; SHF-separate hydrolysis and fermentation. 
Hydrogen is a naturally occurring molecule that can serve as a clean and efficient energy carrier. Studies have confirmed that microalgae possess the genetic, metabolic, and enzymatic properties required to produce $\mathrm{H}_{2}$ through biochemical conversion [149]. Under anaerobic conditions, eukaryotic algae generate hydrogen as an electron donor in their metabolic pathways as part of the $\mathrm{CO}_{2}$ fixation process. This mechanism has been found to occur both in the light and in the absence of any light sources [150]. During photosynthesis, algae convert the water molecule into a hydrogen ion $\left(\mathrm{H}^{+}\right)$ and oxygen. The $\mathrm{H}^{+}$ions are then converted by hydrogenase into molecular hydrogen $\left(\mathrm{H}_{2}\right)$ under anaerobic conditions [151]. It has been demonstrated that, if photosynthesis is initiated and oxygen is present in the photosynthetic environment, inhibition of the key enzyme (hydrogenase) follows shortly, directly affecting hydrogen production by algae [152].

Most of the scientific publications on this subject reported that the single-cell Chlamydomonas reinhardtii algae, commonly found in soil and saltwater, can produce $\mathrm{H}_{2}$ with high efficiency (Table 8) $[153,154]$. The hydrogen production capacity of 21 green algae species in an isolated anaerobic environment was also examined. The most productive strains were C. reinhardtii, C. euryale, C. noctigama, C. vectensis, C. pyrenoidosa, Oocystis, D. subspicatus, and P. subcapitata. Publications reported $\mathrm{H}_{2}$ yields of $90-110 \mathrm{~cm}^{3} \mathrm{H}_{2} \cdot \mathrm{dm}^{-3}$ for these organisms, with even higher levels of $80-140 \mathrm{~cm}^{3} \mathrm{H}_{2} \cdot \mathrm{dm}^{-3}$ reached in some cases [155]. Ample publications have shown that Platymonas subcordiformis algae can be used for the technological production of biohydrogen (Table 8). The method employs alternating dark and light cycles with external carbon dosing, and it can produce $\mathrm{H}_{2}$ yields of $78.0 \mathrm{~cm}^{3} \mathrm{H}_{2} \cdot \mathrm{dm}^{-3}$ to as high as $126 \mathrm{~cm}^{3} \mathrm{H}_{2} \cdot \mathrm{dm}^{-3}[156,157]$.

Table 8. Microalgal biohydrogen production.

\begin{tabular}{ccc}
\hline Microalgal Strains/Biomass & Hydrogen Yield $\left.\mathbf{( \mathbf { c m } ^ { \mathbf { 3 } } \cdot \mathbf { d m }} \mathbf{\mathbf { 3 }}\right)$ & Ref. \\
\hline Chlamydomonas reinhardtii & 5.2 & {$[158]$} \\
Chlamydomonas reinhardtii & 210.9 & {$[159]$} \\
Chlamydomonas reinhardtii & 120.0 & {$[155]$} \\
Chlorella sp. & 150.0 & {$[160]$} \\
Platymonas Subcordiformis & 50.0 & {$[161]$} \\
Platymonas Subcordiformis & 157.7 & {$[162]$} \\
Tetraselmis Subcordiformis & 55.8 & {$[163]$} \\
\hline
\end{tabular}

Methane fermentation can also be employed to convert algal biomass into a gaseous energy carrier through biochemical processes (Table 9). According to available estimates, the conversion of algal biomass into biogas is a highly cost-effective and commercially viable technological solution comparable to cellular lipid extraction in terms of harvested energy [164,165]. In addition to high-energy biogas, the process also produces digestate, which can be used directly as a fertilizer for terrestrial plants or reintroduced into the algal biomass route as a medium component after simple processing [166].

The practical limitations of technological processes involving methane fermentation of algae may stem from their biochemical composition. Algal biomass mostly consists of proteins and, thus, may lead to deficient $\mathrm{C}: \mathrm{N}$ ratios. This problem can be greatly alleviated through the co-digestion of the algal biomass with organic substrates rich in carbon compounds. Yen and Brune (2007) achieved a substantial increase in methane production by co-digesting cellulose waste with algal biomass. The methane production rate rose to $1170 \pm 75 \mathrm{~cm}^{3} \cdot \mathrm{dm}^{-3} \cdot$ day $^{-1}$ at a $1: 1$ ratio of organic waste and algal biomass, as compared to $573 \pm 28 \mathrm{~cm}^{3} \cdot \mathrm{dm}^{-3}$. day ${ }^{-1}$ achieved for mono-digestion of algae alone [167].

The high protein content of the algal biomass may lead to an increased production of free ammonia, which is toxic to the methane-fermenting microorganisms. Methanogenesis can also be inhibited by the sodium ions present in the algal biomass from saltwater-based cultivation systems. However, some studies show that anaerobic sludge microorganisms can be adapted and incorporated into the process for the efficient digestion of marine algal biomass $[168,169]$. 
Table 9. Production of bio-oil from microalgal biomass.

\begin{tabular}{|c|c|c|c|c|c|}
\hline \multirow[t]{2}{*}{ Microalgal Strains/Biomass } & \multicolumn{2}{|c|}{$\begin{array}{c}\text { Methane Fermentation } \\
\text { Condition }\end{array}$} & \multirow[t]{2}{*}{$\begin{array}{l}\text { Biogas Yield } \\
\left(\mathrm{cm}^{3} \cdot \mathrm{g}^{-1} \mathrm{VS}\right)\end{array}$} & \multirow[t]{2}{*}{$\begin{array}{l}\text { Methane Yield } \\
\left(\mathrm{cm}^{3} \cdot \mathrm{g}^{-1} \text { VS) }\right.\end{array}$} & \multirow[t]{2}{*}{ Ref. } \\
\hline & $\mathrm{T}\left({ }^{\circ} \mathrm{C}\right)$ & Time (days) & & & \\
\hline Arthrospira platensis & 38 & 32 & 481 & 293.41 & [170] \\
\hline $\begin{array}{l}\text { Botrycoccus braunii } \\
\text { (pretreated biomass) }\end{array}$ & 30 & 45 & - & 521 & [171] \\
\hline Botryococcus braunii & 35 & $34-50$ & - & $343-370$ & [172] \\
\hline Chlamydomonas reinhardtii & 38 & 32 & 587 & 387.42 & [170] \\
\hline Chlamydomonas sp. & 35 & $34-50$ & - & 333 & [172] \\
\hline Chlorella kessleri & 38 & 32 & 335 & 217.75 & [170] \\
\hline Chlorella minutissima & 36 & - & 340 & 166.12 & [173] \\
\hline Chlorella pyrenoidosa & 36 & - & 464 & 264.71 & [173] \\
\hline Chlorella sorokiniana & 30 & 42 & - & 298 & [174] \\
\hline $\begin{array}{l}\text { Chlorella sorokiniana } \\
\text { (pretreated biomass) }\end{array}$ & 30 & 42 & - & 388 & [174] \\
\hline Chlorella sorokiniana & $40-41$ & 71 & 248 & 212 & [175] \\
\hline Chlorella vulgaris & 36 & - & 369 & 195.64 & [173] \\
\hline Chroococcus sp. & 36 & 30 & 487 & 267.36 & [176] \\
\hline Dunaliella salina & 38 & 32 & 505 & 323.2 & [170] \\
\hline Euglena gracilis & 38 & 32 & 485 & 324.95 & [170] \\
\hline Isochrysis sp. & 35 & $34-50$ & - & 408 & [172] \\
\hline Macrocystis pyrifera & 37 & 31 & - & 545 & [177] \\
\hline Nannochloropsis oculata & 35 & 30 & - & 204 & [178] \\
\hline $\begin{array}{l}\text { Nannochloropsis salina } \\
\text { (lipid extracted biomass) }\end{array}$ & 37 & 40 & - & 130 & [179] \\
\hline Scenedesmus dimorphus & 35 & $34-50$ & - & 397 & [172] \\
\hline Scenedesmus obliquus & 38 & 32 & 287 & 177.94 & [170] \\
\hline
\end{tabular}

VS-volatile solids

Many researchers have argued that methane fermentation is the most promising and effective method for producing energy from algae. Sialve et al. (2009) found that, given suitable operating conditions, methane fermentation as a primary method of algal biomass processing is more economical than systems that incorporate lipid extraction and anaerobic processing of post-extraction residues [165]. Other findings suggest that the balance of methane fermentation unit operations is the most effective in terms of both the economy of the process and the pollution levels [180]. Studies have indicated that methane fermentation may be the most practical means of converting algal biomass into energy. However, Börjesson and Berglund (2006) noted that energy inputs and environmental impact varied greatly between the different methane fermentation technologies [181]. As such, an environmental life-cycle assessment (LCA) is necessary for a complete and objective evaluation of each process [182].

To meet the current challenges related to the circular bioeconomy, it is necessary to change the approach to biorefinery processes [183]. Technological, economic, and environmental efficiency improvements can be achieved by simultaneously producing many high-value products other than biofuels $[184,185]$. Research and development works must, therefore, be focused on finding new, more complex, and integrated production processes. Although various strategies have been proposed for converting algal biomass into fuel and fine chemicals, none have been proven to be economically viable and energy balanced [186]. Therefore, other, valuable biological products should also be searched for. In this context, the concept of microalgae biorefineries emerged with the concept of recovering multiple products from one operating process. Considering the biorefinery complexity index (BCI) as an indicator of technical and economic risk, one of the most promising seems to be the biorefinery platform based on microalgal biomass conversion into fuels, food, dietary and feed supplements, fertilizers, and pharmaceuticals [187]. A schematic diagram of a comprehensive biorefinery approach to the processing of microalgal biomass is presented below (Figure 3). 


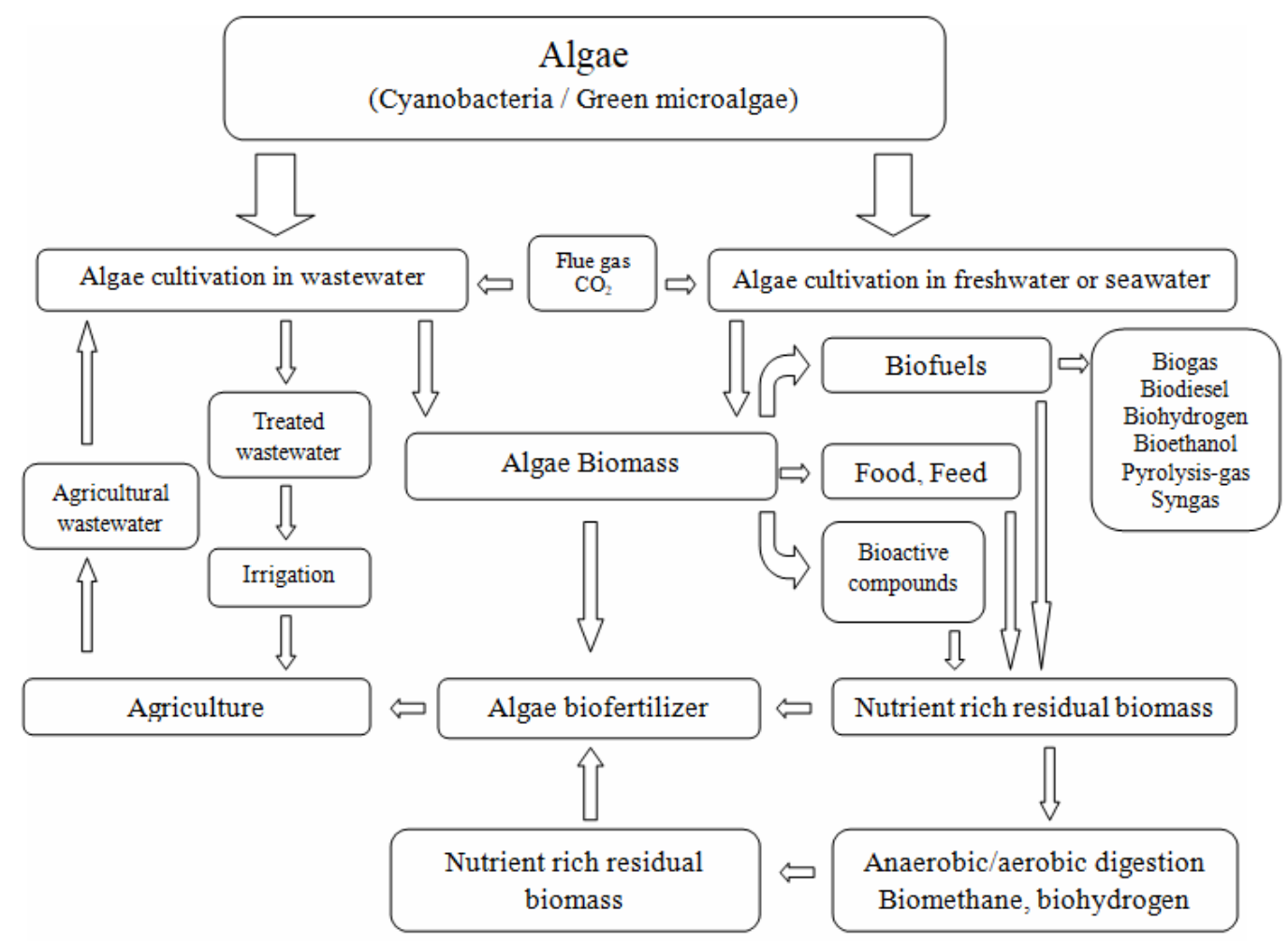

Figure 3. A schematic diagram of a comprehensive biorefinery approach to microalgal biomass processing.

\section{Systems of Microalgae Species Cultivation for Biofuel}

The growth rate of microalgae and their composition is influenced by the growth conditions and the species employed [188-190]. Many classification schemes categorize methods and technologies used to cultivate algae for biofuel [191,192]. Due to the specific nature of microalgae, the most important scheme divides the systems on the basis of the nutrient source and the type of biochemical processes used to grow the algal biomass rapidly. With this criterion in mind, cultures can be divided into four main types: photoautotrophic, heterotrophic, mixotrophic, and photoheterotrophic [193]. The advantages and disadvantages of each type are presented in Table 10.

Table 10. Comparison of features and challenges of algal cultivation methods.

\begin{tabular}{|c|c|c|c|c|}
\hline Type of Culture & Type & Advantages & Issues & Ref. \\
\hline \multirow[t]{2}{*}{ Photoautotrophic } & $\begin{array}{c}\text { Closed } \\
\text { photobioreactors }\end{array}$ & $\begin{array}{c}\text { Water saving } \\
\text { Greater long-term culture } \\
\text { maintenance } \\
\text { High yield }\end{array}$ & $\begin{array}{c}\text { High cost } \\
\text { Temperature control } \\
\text { (requires cooling) } \\
\text { Maximum light exposure } \\
\text { Periodic cleaning }\end{array}$ & [194] \\
\hline & Open ponds & $\begin{array}{c}\text { Lower costs } \\
\text { Evaporative cooling }\end{array}$ & $\begin{array}{c}\text { Low yield } \\
\text { Changes in humidity and } \\
\text { temperature } \\
\text { Maximum light exposure }\end{array}$ & [194] \\
\hline Heterotrophic & $\begin{array}{c}\text { Closed } \\
\text { photobioreactors }\end{array}$ & $\begin{array}{c}\text { Easy to maintain } \\
\text { High biomass } \\
\text { concentrations } \\
\text { Contamination } \\
\text { prevention } \\
\text { Utilization of inexpensive } \\
\text { lignocellulosic sugars }\end{array}$ & $\begin{array}{l}\text { Competition with other } \\
\text { biofuel technologies for } \\
\text { feedstock }\end{array}$ & [194] \\
\hline
\end{tabular}


Table 10. Cont.

\begin{tabular}{|c|c|c|c|c|}
\hline Type of Culture & Type & Advantages & Issues & Ref. \\
\hline Mixotrophic & Photobioreactor & $\begin{array}{l}\text { Two-route cultivation, } \\
\text { easy to bioremediate } \\
\text { Uses organic compounds } \\
\text { as energy source, } \\
\text { provides superior energy } \\
\text { recovery and carbon } \\
\text { footprint }\end{array}$ & $\begin{array}{l}\text { Design needs to be } \\
\text { upgraded to improve } \\
\text { operation and economy } \\
\text { Rarely used for bio-oil } \\
\text { production } \\
\text { Not used for biodiesel } \\
\text { production }\end{array}$ & [195-197] \\
\hline Photoheterotrophic & Photobioreactor & $\begin{array}{l}\text { Fast growth of algae and } \\
\text { synthesis of valuable } \\
\text { metabolites (i.e., fatty } \\
\text { acids) }\end{array}$ & $\begin{array}{c}\text { Requires light as an } \\
\text { energy source, unlike } \\
\text { mixotrophic cultivation } \\
\text { Not used for biodiesel } \\
\text { production }\end{array}$ & {$[193,196,197]$} \\
\hline
\end{tabular}

In a photoautotrophic culture, microalgae use light as their source of energy, as well as carbon dioxide and water to synthesize organic compounds [198]. This type of algae culture is most commonly used for commercial applications [199]. Studies have shown photoautotrophic cultures to exhibit great variability in algal biomass lipid content, with values ranging from $5 \%$ to $68 \%$ depending on the tested strain. A study with Chaetoceros calcitrans CS 178 showed a lipid production rate of $r_{\text {LIP }}=17.6 \mathrm{mg} \cdot \mathrm{dm}^{-3} \cdot$ day $^{-1}$ and a final lipid content of $39.8 \%$ dry matter [91]. In contrast, a Botryococcus braunii UTEX 572 culture ended in the lipid production yield of $\mathrm{r}_{\text {LIP }}=5.5 \mathrm{mg} \cdot \mathrm{dm}^{-3} \cdot \mathrm{day}^{-1}$ [199]. The highest productivity was obtained in a study that tested the impact of high concentrations of $\mathrm{CO}_{2}$ on biomass growth and lipid synthesis in Chlorella sp. culture. The final lipid concentration reached $32-34 \%$ cell dry matter, with a maximum lipid production rate of $\mathrm{r}_{\mathrm{LIP}}=179.8 \mathrm{mg} \cdot \mathrm{dm}^{-3} \cdot \mathrm{day}^{-1}[200]$.

Like bacteria and fungi, some microalgae species are capable of heterotrophic growth using organic carbon sources, such as glucose and glycerol [196,201]. Heterotrophic cultivation can be used to avoid the problem endemic to photoautotrophic systems, i.e., overgrown photobioreactor surfaces and the microalgal growth blocking its own light source, thus limiting the energy supply necessary for efficient photosynthesis, biomass growth, and lipid synthesis [198]. Heterotrophic cultures are characterized by higher growth rates and final biomass/lipid concentrations than the phototrophic or mixotrophic cultures. For example, a heterotrophic culture of Crypthecodinium cohnii-a strain known for its ability to biosynthesize omega-3 acids-grown on a complex medium of glucose, acetic acid, and yeast extract, produced final concentrations of $109 \mathrm{~g} \cdot \mathrm{dm}^{-3}$ dry biomass and $61 \mathrm{~g} \cdot \mathrm{dm}^{-3}$ lipids in the culture [202].

Changing the culture conditions from photoautotrophic to heterotrophic can increases lipid content per cell dry matter for some microalgal strains. For example, a 40\% increase in lipid content was observed in a Chlorella protothecoides culture after the cultivation scheme was changed from photoautotrophic to heterotrophic [96]. In another study, changing the conditions from phototrophic to heterotrophic led to an over tenfold reduction in the final biomass concentration in a C. vulgaris ESP-31 culture [203]. In the lipid analysis of Chlorella protothecoides cultures, Caporgno et al. (2019) achieved fatty acid contents at $11.8 \% \pm 0.1 \%$ dry weight (DW) and below $6 \%$ DW under heterotrophic and photoautotrophic conditions, respectively [204]. Sim et al. (2019) also observed an increased lipid production by Chlorella protothecoides. It reached $18.4 \% \pm 0.4 \%$ DW under conditions of the heterotrophic culture and $15.1 \% \pm 0.3 \%$ DW under photoautotrophic conditions [205]. Shen et al. (2019) demonstrated an increase in fatty acid production by Chlorella vulgaris that ranged from $14.9 \pm 2.1 \mathrm{mg} \cdot \mathrm{dm}^{-3} \cdot \mathrm{day}^{-1}$ under photoautotrophic conditions to $51.4 \pm 14.6 \mathrm{mg} \cdot \mathrm{dm}^{-3} \cdot \mathrm{day}^{-1}$ in the heterotrophic culture [206]. Li et al. (2016) obtained maximum biomass production in the photoautotrophic culture of Chlorella sorokiniana, reaching $0.36 \pm 0.01 \mathrm{~g} \cdot \mathrm{dm}^{-3}$ at a specific grow th rate of $0.60 \pm 0.01 \mathrm{day}^{-1}$. Under heterotrophic conditions, the respective values were $2.78 \pm 0.06 \mathrm{~g} \cdot \mathrm{dm}^{-3}$ and $1.56 \pm 0.02 \mathrm{day}^{-1}$ [207]. In turn, Zheng et al. (2012) proved that the growth rate, cell density, and productivity of heterotrophic Chlorella sorokiniana were 
3.0, 3.3, and 7.4 times higher than their phototrophic counterpart, respectively [208]. Lastly, Li et al. (2014) achieved the lipid content at 9.0\% DW in the photoautotrophic culture of Chlorella sorokiniana and at $6.2 \%$ to $17.6 \% \mathrm{DW}$ in the heterotrophic cultures [209].

Microalgae have been shown to take up many different organic carbon sources, including glucose, acetate, glycerol, fructose, sucrose, lactose, galactose, and mannose [97,210]. De Swaaf (2003) presented a study examining the use of different organic substrates in a heterotrophic culture, utilizing acetic acid and its feeding regime in a pH-controlled culture to grow Crypthecodinium cohnii [202]. This technological solution resulted in very high values of the final productivity parameters, i.e., final cell dry matter concentration at $109 \mathrm{~g} \cdot \mathrm{dm}^{-3}$ and $61 \mathrm{~g} \cdot \mathrm{dm}^{-3}$ lipids in the culture. Other studies showed Chlorella protothecoides to be capable of growth in a batch culture with crude glycerol as the sole carbon source in the medium, with the final biomass concentration at $23.5 \mathrm{~g} \cdot \mathrm{dm}^{-3}$ and the final lipid concentration at $14.6 \mathrm{~g} \cdot \mathrm{dm}^{-3}$ after a 6 day cultivation [211]. In turn, a semi-continuous batch-fed regime allowed increasing the lipid production rate to $3 \mathrm{~g} \cdot \mathrm{dm}^{-3} \cdot \mathrm{day}^{-1}$ [211].

However, heterotrophic cultivation certainly has its disadvantages, including the frequent contamination of the culture with other strains of microalgae, fungi, and bacteria, reducing the final productivity of the technology and, in some cases, inhibiting fermentation [96,212,213]. One instance of this problem was described by Zhang et al. (2012) who investigated the impact of bacterial contamination on the dry biomass yield and lipid productivity in a heterotrophic culture of Chlorella pyrenoidosa, with soybean-processing wastewater used as a medium. On the one hand, the introduction of bacteria improved nitrogen and phosphorus degradation rates while reducing the chemical oxygen demand. On the other hand, the bacteria also reduced the final concentrations of microalgal biomass and lipids [214]. One of the methods used to avoid contamination of heterotrophic microalgal cultures entails spiking the medium with antibiotics, such as chloramphenicol [215].

In the mixotrophic cultivation, microalgal cells perform photosynthesis with simultaneous uptake of organic and inorganic carbon substrates [216]. Microalgae absorb organic compounds, and the $\mathrm{CO}_{2}$ released through respiration is captured and reused as a substrate for photosynthesis [217]. Unlike phototrophic and heterotrophic systems, the mixotrophic cultivation is rarely employed for the production of microalgae-derived bio-oil. One example of a mixotrophic culture was found in a study by Bhatnagar et al. (2011), who examined the growth rates of Chlamydomonas globosa, Chlorella minutissima, and Scenedesmus bijuga in the three most common cultivation modes. Supplementing Chlamydomonas globosa, Chlorella minutissima, and Scenedesmus bijuga cultures with $1 \%(w / v)$ glucose was found to increase mixotrophic biomass yields 9.4, 6.7, and 5.8 times (respectively) compared to the phototrophic culture and 3.0, 2.0, and 4.4 times compared to the heterotrophic culture [218]. Yu et al. (2009) obtained similar results, demonstrating that the growth rates of Nostoc flagelliforme biomass in glucose-amended media were the highest in the mixotrophic culture, with productivity values 5.0 and 2.3 times those obtained in the phototrophic and heterotrophic cultures, respectively [219].

Though microalgal oil yields are in large part determined by the choice of strain, the heterotrophic cultivation is the most effective solution in terms of the final operational performance, i.e., the biomass concentration in the system and lipid content in cells. As such, the heterotrophic method has generated strong interest among companies involved in the commercialization of bioenergy technologies and research teams working to develop such systems [220]. The most serious drawback of this scheme is the risk of culture contamination with other microorganisms, including other microalgae, which leads to severe complications with the operation of industrial-scale installations [215]. Moreover, the high cost of pure organic carbon sources limits the utility of this cultivation mode to the production of secondary or primary metabolites with a high market value [221].

Photoautotrophic cultures are the most widespread mode of cultivation, easy to scale up through the use of open or hybrid systems [222]. It is also a promising method, due to the capability of photoautotrophic microalgae for the uptake of waste $\mathrm{CO}_{2}$, such as that generated by cogeneration plants, breweries, or biogas plants. However, the oil yields produced via this method are usually vastly inferior to the heterotrophic cultivation, with slow cell growth and low biomass productivity as 
the main reasons. Nevertheless, with this mode being cheaper to scale up, it is highly attractive to investors despite the flaws.

The defining feature of photoheterotrophic cultivation is the use of light, required for the absorption and decomposition of organic carbon. The main difference between mixotrophic and photoheterotrophic modes is that the latter requires light as an energy source, whereas mixotrophic cultivation uses organic compounds for the same purpose. Therefore, photoheterotrophic cultivation requires a combined supply of carbohydrates and light [196]. Although photoheterotrophic systems can be used to increase the production of certain expensive secondary metabolites, the method has not found use in the production of biodiesel, as is the case with mixotrophic microalgal cultures [197].

Prior to undertaking any metabolic engineering work in microalgae, it is necessary to understand the key enzymes involved in the metabolic pathway and the rate-limiting enzymes. Many advances have been made toward understanding lipid metabolism and regulatory factors in soybean and rapeseed, but the lipid production in microalgae at a molecular level is currently very poorly understood. The first step in de novo synthesis of triacylglycerol in microalgae starts in the plastid, where pyruvate is produced from glycolysis and the Calvin cycle. The pyruvate is converted into acetyl-CoA by the pyruvate dehydrogenase complex (PDC). Acetyl-CoA is converted into malonyl-CoA by acetyl-CoA carboxylase (ACCase). Acetyl-CoA carboxylase is the rate limiting enzyme for lipid biosynthesis [223]. Malonyl-CoA is converted into malonyl-ACP by malonyl-CoA transacylase (MAT) [224]. Malonyl-ACP and acyl-ACP are converted into 3-ketoacyl-ACP by 3-ketoacyl-ACP reductase (KAS) in the fatty acid synthesis cycle. 3-Ketoacyl-ACP is converted into 3-hydroxyacyl-ACP by 3-ketoacyl-ACP reductase (KAR). 3-Hydroxyacyl-ACP is converted into trans-enoyl-ACP by 3-hydroxyacyl-ACP dehydratase (HD). trans-Enoyl-ACP is converted into acyl-ACP by enoyl-ACP reductase (ENR). Acyl-ACP is converted into free fatty acids (FFAs) by fatty acyl-ACP thioesterase (FAT) $[225,226]$. The FFAs are transferred into the cytosol and then endoplasmic reticulum for conversion into triacylglycerol (TAG) in the microalgae. The free fatty acids are converted into acyl-CoA by long-chain acyl-CoA synthetase. Acyl-CoA and glycerol 3-phosphate are converted into lysophosphatidic acid by glycerol 3-phosphate acyltransferase (GPAT). Lysophosphatidic acid is converted to phosphatidic acid by lysophosphatidic acid acyltransferase (LPAT). Phosphatidic acid is converted into diacylglycerol by phosphatidic acid phosphatase (PAP). Diacylglycerol is converted into triacylglycerol (TAG) by diacylglycerol acyltransferase (DGAT). Triacylglycerol forms the TAG lipid body [226,227].

Hydrogen production in biological processes conducted by algae is based on the direct biophotolysis, which consists of the photosynthetic production of hydrogen from water, in which the energy of light is used to break the water molecule into hydrogen and oxygen [228]. It takes place mainly due to hydrogenase, which catalyzes the reversible oxidation of $\mathrm{H}_{2}$ and releases gaseous hydrogen by reducing protons $[229,230]$. Two transmembrane peptide complexes are responsible for hydrogen production in the photolysis process by microalgae: photosystem I (PSI) and photosystem II (PSII). The exposure of both complexes to solar radiation results in a water molecule breakdown. Then, $\mathrm{O}_{2}$ is produced by PSII, while PSI uses the electrons generated in this process to reduce $\mathrm{CO}_{2}$ and build cellular material (aerobic conditions), or the electrons are transferred by ferredoxin to hydrogenase and used for hydrogen production [231,232]. Another biochemical process led by algae to produce hydrogen is indirect biophotolysis. It has been proven to occur in the organisms of cyanobacteria, which accumulate carbohydrates resulting from $\mathrm{CO}_{2}$ reduction as a result of photosynthesis, which in turn are decomposed by fermentation mediated by photosystem I. The PSI proteins transfer electrons to ferredoxin using light energy [228,232]. In the indirect biophotolysis process, an important role is played by carbon dioxide, which is a carrier of electrons and protons formed during the water molecule degradation, and by enzymes, including two NiFe hydrogenases and nitrogenase, which catalyze atmospheric nitrogen reduction to ammonia with simultaneous proton reduction and hydrogen release $[233,234]$. 


\section{Strengths and Weaknesses of Different Technologies for Producing and Utilizing Microalgal Biomass}

Microalgae-based technologies of sewage treatment, pollutant degradation, and biofuel production were described in detail in scientific papers, patent claims, and performance data from existing installations [235-237]. Microalgal biomass has been demonstrated to be one of the most efficient and environmentally friendly alternative energy sources, as it is a promising and sustainable source of bio-oil, methane, and biohydrogen, i.e., fuels that can help reduce atmospheric greenhouse gas emissions $[238,239]$. Microalgae represent an alternative to terrestrial vascular plant species commonly used as a biofuel feedstock, such as rapeseed, soybean, and oil palm [240]. Literature data indicate that the annual hectare yield of bio-oil from microalgal cultures can exceed $19 \mathrm{~m}^{3}$. By comparison, the corresponding values are $6.1 \mathrm{~m}^{3}$ for oil palm, $4.3 \mathrm{~m}^{3}$ for sugar cane, $2.4 \mathrm{~m}^{3}$ for corn, and $0.5 \mathrm{~m}^{3}$ for soybean [91,241].

The undeniable strength of the microalgae-based technologies is their well-established high photosynthetic efficiency. The efficiency of the solar-to-chemical energy conversion via algal photosynthesis varies from $4 \%$ to $10 \%$, whereas the range for higher plants is $0.5-2.2 \%[235,242]$. This directly translates to a fast growth rate of microalgae and a high per unit dry matter yield, significantly higher than that of terrestrial plants $[235,240]$. Those observations were corroborated by Tredici et al. (2015), who tested the strain Tetraselmis suecica in a proprietary photobioreactor design named "Green Wall Panel-II" The research was conducted in Italy (Tuscany), with the final productivity of the culture reaching 36 tons of dry microalgal biomass.ha ${ }^{-1} \cdot$ year $^{-1}$. By contrast, soybean grain yields are only 2.6 tons $\cdot \mathrm{ha}^{-1} \cdot \mathrm{year}^{-1}$ [243].

Some strains of microalgae can double their mass in just a few hours. This property was described by Maxwell et al. (1994), who tested the growth rate of Chlorella vulgaris. The generation time observed for the species was $8.6 \mathrm{~h}$ at $27^{\circ} \mathrm{C}$, although cell division extended to $48.5 \mathrm{~h}$ at $5^{\circ} \mathrm{C}$ [244]. Raslavicius et al. (2014) and Chen et al. (2015) showed that the annual microalgal biomass yields per hectare can range from 4 tons of dry matter to as high as 100 tons of dry matter $[235,245]$. According to other works, microalgae can double in volume or mass within a few hours, given the right conditions [238,240,242]. The resultant microalgal biomass yields can reach $500 \mathrm{~kg} \cdot \mathrm{day}^{-1}$ in a $1000 \mathrm{~m}^{2}$ open pond production system [246].

One indisputable advantage of the microalgae-based solutions is that waste substrates of various properties and characteristics can be used to support rapid biomass growth [34]. Such technologies are most often used for tertiary treatment of urban or industrial waste in maturation or facultative ponds [247]. Such organisms release $1.50-1.92 \mathrm{~kg} \mathrm{O} \cdot \mathrm{kg}^{-1}$ of the produced biomass through photosynthesis, with the oxygenation rate reached during degradation of organic pollutants ranging from 0.48 to $1.85 \mathrm{~kg} \mathrm{O}_{2} \cdot \mathrm{m}^{-3}$. day $^{-1}$ [248,249]. Microalgae absorb a significant portion of the biogenic substances contained in wastewater, as they require large quantities of nitrogen and phosphorus for internal protein synthesis. As such, protein content in the algae dry matter ranges from $20 \%$ to $60 \%$, depending on the species. The absorbed biogenic compounds are also used to synthesize nucleic acids and phospholipids [250].

Currently, microalgae-based wastewater treatment processes are often integrated into systems designed to grow algal biomass for biofuel and energy production [251]. Such solutions can be used to remove chemical and biological contaminants from wastewater, while concurrently growing biomass for biofuel production, thus proving to be more viable from the economic and technological standpoint [252]. The use of wastewater as a growth medium directly reduces the costs of supplying water and nutrients necessary for the algae to grow at an efficient rate [253]. Research so far has shown that high $\mathrm{CO}_{2}$ levels in wastewater promote microalgal growth, thus directly stimulating faster degradation of pollutants [254]. In systems where algae are grown in saltwater, the introduction of wastewater also serves to balance the molecular ratio of carbon, nitrogen, and phosphorus ( $\mathrm{C}: \mathrm{N}: \mathrm{P}=106: 16: 1)$, known as the Redfield ratio [255]. 
In light of the widely discussed effects of greenhouse gas emissions, integrated systems capable of reducing gas pollutant levels in the air, while simultaneously harvesting biomass and recovering energy, have attracted much interest [252]. One of the most promising and prospective avenues of evolving such systems lies in using microalgal biomass to remove pollutants from waste gases, mainly $\mathrm{CO}_{2}, \mathrm{NO}_{2}$, and $\mathrm{SO}_{2}[28,256]$. Research to date has shown that intensive microalgae cultivation requires a supply of $1.83 \mathrm{~kg} \mathrm{CO}$ per $1.0 \mathrm{~kg}$ of the grown dry matter, which is why low carbon dioxide concentrations in the growth medium often present a bottleneck that impedes rapid biomass growth [200]. Therefore, additional $\mathrm{CO}_{2}$ needs to be loaded into the photobioreactor by increasing saturation or enriching the culture with leachate from the digesters [29]. Some promising studies on carbon dioxide fixation in algae cultivation systems indicate that the technology may potentially be used to lower $\mathrm{CO}_{2}$ emissions [28,29].

One advantage of intensive algae production systems is that microalgal biomass can be grown in both freshwater and saltwater media. Kuei-Ling and Jo-Shu (2012) examined Chlorella vulgaris ESP-31 growth in freshwater using a modified Bristol's medium and MBL medium, producing biomass concentrations of 2.0-5.0 $\mathrm{g}$ dry matter $\cdot \mathrm{dm}^{-3}$ for both media [203]. In another study involving Nannochloropsis salina CCAP849 grown in saltwater and F/2 medium, Beacham et al. (2015) obtained a final microalgal cell concentration of $7 \times 10^{7} \mathrm{cell} \cdot \mathrm{cm}^{-3}$ [257]. Unlike terrestrial plants, microalgae do not require fertile farmland to thrive $[242,258]$ and can live, effectively photosynthesize, and build biomass in various climate conditions [238].

Eutrophic and degraded water bodies can be used as another promising source of microalgal biomass $[259,260]$. Extracting microalgae from such reservoirs leads to a direct improvement in water quality [240,261]. Microalgae blooms, particularly cyanobacteria blooms, pose a threat to regions attractive to tourists and disrupt the basic processes of natural water bodies [262]. For example, Lake Taihu in China, a source of potable water for over two million people, has been repeatedly struck by cyanobacteria blooms since 2007 , impacting water quality and posing a technological challenge concerning water treatment [263]. Some researchers have attempted to use microalgae from Lake Taihu as an organic substrate for biogas production [263,264]. Microalgal blooms, most of which are cyanobacteria blooms, are increasingly occurring in water bodies worldwide. Lake Chaohu and Lake Dianchi are among the reservoirs that regularly experience algal blooms [265].

Controlled cultivation of microalgae in eutrophic sea waters has been shown to directly lower biogenic compound concentration in the water and reduce the likelihood of marine life loss. Thus, it can be viewed as a method of revegetation used to improve reservoir condition [253]. Some of the associated issues were addressed in a research program launched by the present authors, which in large part aimed to assess the potential of incorporating microalgal biomass sourced from the Lagoon of Wisła and microalgae sourced from the Puck Bay into methane fermentation processes [266-268]. The analysis of the microalgae sourced from the Lagoon of Wisła showed a taxonomically differentiated biomass undergoing season-to-season changes. Bacillariophyceae species prevailed in the spring months from April to May and in the autumn months from October to November. From June to September, the Cyanoprokaryota division species were the most populous, with Chlorophyta and Dinophyceae as the subdominant groups [262]. It was shown that the time of microalgae extraction from Lagoon of Wisła waters had a significant effect on the organic compound concentration in phytoplankton dry matter. The lowest concentrations were recorded for the Bacillariophyceae-dominant period, whereas the highest ones were correlated with Cyanoprokaryota and Chlorophyta presence [262]. Respirometric analyses showed that the technological performance of the methane fermentation process was the highest in the variants utilizing algal biomass extracted between June and September (i.e., rich in Cyanoprokaryota and, to a lesser extent, Chlorophyta) loaded into model digesters. Biogas yields within this period ranged between $389.07 \pm 8.21$ and $420.95 \pm 0.95 \mathrm{~cm}^{3} \cdot \mathrm{g}$ dry matter ${ }^{-1}$ [262].

Microalgae can be grown in water sourced from natural reservoirs (with a high content of biogenic substances), as well as in liquid waste and wastewater of various compositions. The use of such culture media not only leads to increased biomass productivity but can also deliver positive 
environmental outcomes. Microalgae employed in a photobioreactor with a scrubber allowed for a $60-90 \%$ reduction in nitrogen content and $70-100 \%$ reduction in phosphorus content in an effluent from manure condensation [269]. Microalgae-based technological systems also offer the advantage of pesticide-free cultivation, which significantly reduces the risk of secondary environmental pollution [238]. Characteristics of microalgal biomass culture systems are collated in Table 11.

Table 11. Characteristics of microalgal biomass culture systems—summary.

\begin{tabular}{|c|c|c|c|}
\hline \multicolumn{3}{|c|}{ Advantages/Disadvantages of Microalgal Biomass Production and Use } & Ref. \\
\hline \multicolumn{2}{|c|}{ Culture efficiency } & 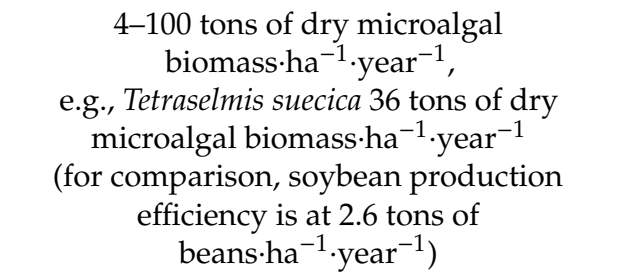 & {$[235,243,245]$} \\
\hline \multirow[t]{2}{*}{ Culture medium } & Fresh water & $\begin{array}{l}2.0-5.0 \mathrm{~g} \text { weight } \cdot \mathrm{dm}^{-3} \text { using } \\
\text { Chlorella vulgaris ESP- } 31 \text { strain and a } \\
\text { modified Bristol medium or MBL }\end{array}$ & [203] \\
\hline & Salt water & $\begin{array}{c}7 \times 10^{7} \text { cells of microalgae } \cdot \mathrm{cm}^{-3} \text { using } \\
\text { Nannochloropsis salina CCAP849 strain and } \\
\text { F/2 culture medium }\end{array}$ & [257] \\
\hline \multicolumn{2}{|c|}{ High photosynthetic efficiency } & $\begin{array}{c}4-10 \% \\
(0.5-2.2 \% \text { in the case of higher plants })\end{array}$ & {$[235,242]$} \\
\hline \multicolumn{2}{|c|}{ Protein concentration in dry weight } & $20-60 \%$ & [250] \\
\hline \multicolumn{2}{|c|}{$\begin{array}{l}\text { Demand for } \mathrm{CO}_{2} \text { during culture (a factor } \\
\text { impairing high biomass growth) }\end{array}$} & ca. $1.83 \mathrm{~kg} \mathrm{CO} 2 \cdot \mathrm{kg}^{-1}$ of dry biomass grown & [200] \\
\hline \multirow[t]{2}{*}{ Oxidation } & $\begin{array}{l}\text { Oxygen release during } \\
\text { fermentation }\end{array}$ & $\begin{array}{c}1.50-1.92 \mathrm{~kg} \mathrm{O}_{2} \cdot \mathrm{kg}^{-1} \text { of the produced } \\
\text { biomass }\end{array}$ & \multirow[t]{2}{*}[248,249]{} \\
\hline & $\begin{array}{l}\text { Oxidation rate during } \\
\text { degradation of organic } \\
\text { pollutants }\end{array}$ & $0.48-1.85 \mathrm{~kg} \mathrm{O}_{2} \cdot \mathrm{m}^{-3} \cdot$ day $^{-1}$ & \\
\hline \multicolumn{2}{|c|}{ Redfield's ratio in wastewater-based systems } & $\mathrm{C}: \mathrm{N}: \mathrm{P}=106: 16: 1$ & [255] \\
\hline \multicolumn{2}{|c|}{ Bio-oil production } & $\begin{array}{c}19 \mathrm{~m}^{3} \cdot \mathrm{ha}^{-1} \cdot \mathrm{year}^{-1} \\
\text { (for comparison, } 6.1 \mathrm{~m}^{3} \cdot \mathrm{ha}^{-1} \cdot \mathrm{year}^{-1} \text { from } \\
\text { oil palm plantation, } 4.3 \mathrm{~m}^{3} \cdot \mathrm{ha}^{-1} \cdot \mathrm{year}^{-1} \\
\text { from sugar cane, } 2.4 \mathrm{~m}^{3} \cdot \mathrm{ha}^{-1} \cdot \mathrm{year}^{-1} \text { from } \\
\text { maize, and } 0.5 \mathrm{~m}^{3} \cdot \mathrm{ha}^{-1} \cdot \mathrm{year}^{-1} \text { from } \\
\text { soybean) }\end{array}$ & {$[91,241]$} \\
\hline \multicolumn{2}{|c|}{ Biogas production } & $\begin{array}{l}389.07 \pm 8.21-420.95 \pm 0.95 \mathrm{~cm}^{3} \cdot \mathrm{g} \text { dry } \\
\text { matter }^{-1} \\
\text { (with dominating Cyanoprokaryota and } \\
\text { subdominating Chlorophyta) }\end{array}$ & [262] \\
\hline \multicolumn{2}{|c|}{ Use of biogenic compounds } & $\begin{array}{l}\text { Reduction of nitrogen compound } \\
\text { concentration by } 60-90 \% \text { and phosphorus } \\
\text { compound concentration by } 70-100 \% \text { in the } \\
\text { effluent from manure concentration }\end{array}$ & [269] \\
\hline
\end{tabular}

The reservations and controversies surrounding microalgae production/utilization technology mostly relate to the identified investment, technological, and operational barriers to implementation. Such barriers directly impact the costs of biomass cultivation, thickening, and separation. Another dissuading factor is the financial burden connected with converting the biomass into valuable end products $[238,239]$. The investment and operating costs intrinsic to microalgal cultivation are 
several times higher (more than tenfold in some cases) than the costs of extracting lignocellulosic biomass $[246,270]$. As such, the priority task of commercial enterprises and research groups is to increase the cost-effectiveness of such systems [236]. Furthermore, operating microalgae production installations and converting biomass into other products are still subject to many technological hurdles [258]. Gouveia (2011) noted the multiple deficiencies of algae cultivation methods, pointing to the recurring problems with growing microalgae in photobioreactors, i.e., biofilm build-up on photobioreactor walls, blockage of light sources by the growing culture, high oxygen concentrations, and accumulation of compounds toxic to microalgae cells [271]. Other authors also highlighted the importance of these technological problems [60,272,273].

In order to obtain economically profitable, pure cultures and metabolites of microalgae, it is necessary to employ complex substrate compositions, containing nitrogen, phosphorus, iron, silicon, vitamins, and microelements [240,258]. Operators of intensive microalgae production systems face the major technological challenge of ensuring proper composition of the growth medium and monitoring its quality throughout cultivation. The choice of growth medium depends on the tested microalgae species, as well as on the desired product of cultivation. For example, Nannochloropsis oceanica cultivated for biofuel production is grown on BG-11 medium, at $2 \% \mathrm{CO}_{2}(v / v)$, with an artificial light intensity of 80-100 $\mu \mathrm{mol}$ photons $\cdot \mathrm{m}^{-2} \cdot \mathrm{s}^{-1}$ and a temperature of $25^{\circ} \mathrm{C}$ [274]. In contrast, Crypthecodinium cohnii microalgae grown to produce omega- 3 acids need glucose as a source of carbon, yeast extract as a source of nitrogen, a temperature of $27^{\circ} \mathrm{C}$, dark conditions, and oxygen levels of more than $30 \%$ [202].

Improper operation of microalgal biomass production systems may lead to problematic environmental pollution with undigested nutrients. This phenomenon causes adverse changes in the functioning and structure of aquatic ecosystems, leading to accelerated eutrophication. The problem stems in large part from bioreactors being fed with an imbalanced nutrient load. The discharge of effluent rich in excess nutrients into natural reservoirs may result in acidification and water pollution, which in turn lead to ecotoxicity, eutrophication, and degradation [261,275].

Other disadvantages of microalgal biomass technologies relate to the potential competition of algae with food crops and industrial crops, land use and the change thereof, and negative effects on biodiversity [258]. Researchers also pointed to potential disruption of natural aquatic ecosystems [276], ozone depletion [277], and structural restrictions on the market's operation [258]. Additionally, genetically modified microalgae used for cultivation may proliferate in the wild and produce various mutations, including ones detrimental to the environment [261]. The lack of legislative/legal measures and incentives, such as subsidies and tax credits, also presents a barrier to the widespread take-up of microalgae-based technologies, including those relevant to biofuel production [276]. The major advantages and disadvantages of algae and algae-derived fuels are presented in Table 12 [13].

Table 12. Major advantages and disadvantages of algae and algae fuels.

\begin{tabular}{cc}
\hline Advantages & Disadvantages \\
\hline $\begin{array}{c}\text { Renewable, sustainable, effective, } \\
\text { and environmentally friendly biofuel }\end{array}$ & $\begin{array}{c}\text { Incomplete renewable energy resource for biofuels } \\
\text { with respect to complete life cycle assessment }\end{array}$ \\
\hline $\begin{array}{c}\text { Transition to low-carbon economy, i.e., from } \\
\text { hydrocarbons to carbohydrate, protein, and lipid } \\
\text { resources }\end{array}$ & $\begin{array}{c}\text { Insecurity of algae feedstock supply, regional and } \\
\text { seasonal availability, and local energy supply }\end{array}$ \\
\hline $\begin{array}{c}\text { No competition or lower risk of competition with } \\
\text { feeds and foods }\end{array}$ & $\begin{array}{c}\text { Lack of global monitoring and control of algae fuel } \\
\text { production with certification of origin and source }\end{array}$ \\
\hline Energy security, diversification of fuel supply & $\begin{array}{c}\text { Lack of established transparent policy frameworks } \\
\text { and instruments (subsidies, mandates and tax credit } \\
\text { incentives) }\end{array}$ \\
\hline
\end{tabular}


Table 12. Cont.

\begin{tabular}{|c|c|}
\hline Advantages & Disadvantages \\
\hline $\begin{array}{c}\text { Enormous greenhouse gas uptake and superior } \mathrm{CO}_{2} \\
\text { capture and sequestration with extra oxygen release } \\
\text { while growing }\end{array}$ & $\begin{array}{l}\text { Possible competition with edible algae and } \\
\text { biomaterials production }\end{array}$ \\
\hline Conservation of fossil fuels & Utilization of fossil fuels during algae processing \\
\hline $\begin{array}{l}\text { Rural revitalization and social benefits with creation } \\
\qquad \text { of new jobs and income }\end{array}$ & $\begin{array}{l}\text { High production costs for growing, harvesting, } \\
\text { collecting, transporting, storing, and pretreating, } \\
\text { as well as the low cost-effectiveness with high initial } \\
\text { capital investment }\end{array}$ \\
\hline $\begin{array}{l}\text { Mitigation of negative effects of spiking crude oil } \\
\text { prices and reduced dependency on foreign oil imports }\end{array}$ & $\begin{array}{l}\text { The "biofuel only" production approach is not } \\
\text { commercially viable }\end{array}$ \\
\hline High energy conversion efficiency by photosynthesis & $\begin{array}{l}\text { Damage to natural ecosystems (water, soil, } \\
\text { biodiversity conservation, eutrophication, pollution) }\end{array}$ \\
\hline $\begin{array}{l}\text { High productivity with rapid growth rate and high } \\
\text { growing yield }\end{array}$ & $\begin{array}{l}\text { Disruption of the ecological balance in the already } \\
\text { stressed lakes, ponds, seas, and oceans }\end{array}$ \\
\hline $\begin{array}{c}\text { Herbicide or pesticide use is not recommended } \\
\text { during cultivation }\end{array}$ & Harmful algal blooms in global waters \\
\hline Easily cultured and readily and rapidly bioengineered & $\begin{array}{l}\text { Odor, potentially dangerous emissions }\left(\mathrm{Cl}, \mathrm{CH}_{4}, \mathrm{CO}_{2},\right. \\
\mathrm{SO}_{\mathrm{X}}, \mathrm{NO}_{\mathrm{X}} \text {, toxic trace elements), ozone depletion, } \\
\text { and leaching of hazardous components during } \\
\text { disposal and processing }\end{array}$ \\
\hline
\end{tabular}

Use of oceans, seas, ponds, and low-productive,

degraded and contaminated nonarable lands, can grow even in industrial, municipal, and agricultural

Utilization of arable land or land-use changes wastewaters

Readily adaptable to a wide range of climatic conditions

Use of genetically modified organisms in algae cultivation and in production of biofuels

Reclamation of degraded and contaminated areas and ponds

Unclear utilization of waste products

Prevents eutrophication and pollution in aquatic ecosystems

Highly biodegradable resource, quick to bioremediate

Health problems due to neurotoxic properties of some algae

Technological problems during thermochemical processing (separation, agglomeration, deposit formation, slagging, fouling, corrosion, erosion)

Reduction of algae residues and waste

Restrictions on direct combustion and gasification of algae

Plentiful and relatively cheap resource for production of biochemicals, sorbents, fertilizers, building

materials, synthesis of some minerals, and recovery of certain elements and compounds

Lack of accepted terminology, methodologies, standards, and classification and certification systems

High levels of volatiles, Au, B, Br, Ca, I, Mg, P, Ti, carbohydrates, proteins, lipids, structural organic components, extractives, water-soluble nutrient elements

Insufficient knowledge for the assessment and validation; variability of composition, properties, and quality

\begin{tabular}{cc}
\hline Low values of $\mathrm{C}$ and some trace elements & $\begin{array}{c}\text { Algae cultivation occasionally requires high volumes } \\
\text { of nutrient-rich water or fertilizers }\end{array}$ \\
\hline $\begin{array}{c}\text { Great reactivity and low initial ignition and } \\
\text { combustion temperatures during conversion }\end{array}$ & Use of extra water during algae processing \\
\hline $\begin{array}{c}\text { Reduction of some hazardous emissions }\left(\mathrm{CO}_{2}, \mathrm{SO}_{X},\right. \\
\mathrm{NO}, \text { toxic trace elements) by capture and storage of } \\
\text { toxic components in ash }\end{array}$ & Limited practical experience in biofuel production \\
\hline
\end{tabular}




\section{Conclusions}

Pushing forward the development and widespread implementation of clean, effective, and renewable energy technologies represents an ongoing challenge for scientists, as well as a priority issue for operators and administrators of energy systems. There is a widespread perception that this objective can be partly achieved by stimulating the development of unconventional energy generation methods that employ biomass of various characteristics and from various sources. However, this prevailing view is contested by some studies. Mismanagement of traditional energy crop reserves may actually lead to increased greenhouse gas emissions. Other analyses have shown that intensive use of farmland to produce biofuel crops may lead to decreased global food supply and a significant rise in food prices.

Therefore, there is a real need to seek alternative sources of biomass, which would be both commercially and environmentally viable. Algae possess very high photosynthetic efficiency, can rapidly build biomass, are resistant to various contaminants, and can be grown on land that is unsuitable for other purposes. Given these considerations, algae may provide a viable alternative to traditional energy cops. At present, the road to large-scale implementation of technological solutions for the production and use of microalgal biomass is fraught with many economic, technological, and legal difficulties. Unsuitable climate conditions are also a frequent impediment. This means that any microalgae culture facilities should employ technologies that ensure the proper thermal and light conditions-crucial factors in microalgal growth. However, introducing such solutions greatly escalates the investment and operating costs of the technology.

In view of the above, there is a need for solutions that improve the commercial viability of technologies for producing and exploiting microalgal biomass. One of the prospective avenues of improvement is developing and implementing technological solutions that incorporate waste substrates into the growth medium. Sites of anaerobic reactor exploitation can serve as technologically and commercially viable locations for microalgal biomass production, given the supply of ready-to-use biogenic compounds in post-fermentation effluent and carbon dioxide from combusted biogas. Additionally, such installations can provide heat during the cold season. These concepts are fully validated by the fact that the microalgae cultivation systems used thus far in the temperate climate zone are not particularly effective in terms of technology or economy. Therefore, further exploration of novel and alternative solutions is needed to improve the processes of algal biomass proliferation.

Another argument used to defend and support further research on the subject relates to the requirements on the share of biocomponents in the conventional fuel blend and the reduction of greenhouse gas (GHG) emissions. Both of these standards spur the need to implement new technologies of advanced biofuel production that would support the efficient recovery of bioenergy, as well as to implement effective $\mathrm{CO}_{2}$ sequestration methods. The objective is to increase the share of renewable energy sources (RES) in the energy mix, which directly translates into challenges for the European Union (EU) Member States.

Microalgae-based systems are also increasingly considered for applications in engineering and environmental protection, especially wastewater treatment, solid waste neutralization, flue gas reduction, and biofuel production. The usefulness of microalgae in environmental technologies and in the production of valuable products (including energy products) mostly stems from their higher photosynthesis efficiency, faster biomass growth, and capacity to use and remove waste substances compared with typical terrestrial vascular plants. It is reasonable to assume that, even with the multitude of commercial applications described herein, microalgae still hold untapped potential for the implementation in biotechnology and environmental engineering. Microalgae possess properties that grant them a competitive advantage over terrestrial plants in terms of commercial applicability. The physiological and biochemical characteristics of microalgae directly result from their high genetic diversity. This makes it possible to select and adapt specific strains for individual applications, including environmental protection and engineering technologies. The implementation of a biorefinery approach with the concept of recovering many products from one operational process affords an 
opportunity for the development of technologies based on the use of microalgal biomass. Considering the biorefinery complexity index (BCI) as an indicator of technical and economic risk, one of the most promising is a biorefinery platform based on the transformation of microalgal biomass into fuels, food, dietary and feed supplements, fertilizers, and pharmaceuticals.

Author Contributions: Conceptualization, M.D., M.Z. and J.K.; data curation, M.D. and M.Z.; formal analysis, M.D. and M.Z.; funding acquisition, M.D. and M.Z.; investigation, M.D., M.Z., J.K., N.K. and S.T.; methodology, M.D., N.K. and S.T.; project administration, M.D. and M.Z.; resources, M.D., J.K., N.K. and S.T.; software, M.D.; supervision, M.D. and M.Z.; validation, M.D., N.K. and S.T.; visualization, M.D. and J.K.; writing-original draft, M.D., M.Z. and J.K.; writing-review and editing, M.D., M.Z., J.K., N.K. and S.T. All authors read and agreed to the published version of the manuscript.

Funding: Please add: The study was carried out in the framework of the project under the program BIOSTRATEG founded by the National Centre for Research and Development "Processing of waste biomass in the associated biological and chemical processes", BIOSTRATEG2/296369/5/NCBR/2016.

Conflicts of Interest: The authors declare no conflict of interest.

\section{References}

1. Deviram, G.; Mathimani, T.; Anto, S.; Ahamed, T.S.; Ananth, D.A.; Pugazhendhi, A. Applications of microalgal and cyanobacterial biomass on a way to safe, cleaner and a sustainable environment. J. Clean. Prod. 2020, 253, 119770. [CrossRef]

2. Kamani, M.H.; Eş, I.; Lorenzo, J.M.; Remize, F.; Roselló-Soto, E.; Barba, F.J.; Clark, J.H.; Khaneghah, A.M. Advances in plant materials, food by-products, and algae conversion into biofuels: Use of environmentally friendly technologies. Green Chem. 2019, 21, 3213-3231. [CrossRef]

3. Patil, S.; Prakash, G.; Lali, A.M. Reduced chlorophyll antenna mutants of Chlorella saccharophila for higher photosynthetic efficiency and biomass productivity under high light intensities. J. Appl. Phycol. 2020, 32, 1559-1567. [CrossRef]

4. Santhakumaran, P.; Ayyappan, S.M.; Ray, J.G. Nutraceutical applications of twenty-five species of rapid-growing green-microalgae as indicated by their antibacterial, antioxidant and mineral content. Algal Res. 2020, 47, 101878. [CrossRef]

5. Tolboom, S.N.; Carrillo-Nieves, D.; de Jesús Rostro-Alanis, M.; de la Cruz Quiroz, R.; Barceló, D.; Iqbal, H.M.N.; Parra-Saldivar, R. Algal-based removal strategies for hazardous contaminants from the environmentA review. Sci. Total. Environ. 2019, 665, 358-366. [CrossRef] [PubMed]

6. Ziolkowska, J.R. Chapter 1-Biofuels technologies: An overview of feedstocks, processes, and technologies. In Biofuels for a More Sustainable Future; Elsevier: Amsterdam, The Netherlands; Oxford, UK; Cambridge, MA, USA, 2020; pp. 1-19. [CrossRef]

7. Stiles, W.A.V.; Styles, D.; Chapman, S.P.; Esteves, S.; Bywater, A.; Melville, L.; Silkina, A.; Lupatsch, I.; Fuentes, C.; Lovitt, R.; et al. Using microalgae in the circular economy to valorise anaerobic digestate: Challenges and opportunities. Bioresour. Technol. 2018, 267, 732-742. [CrossRef] [PubMed]

8. SundarRajan, P.; Gopinath, K.P.; Greetham, D.; Antonysamy, A.J. A review on cleaner production of biofuel feedstock from integrated CO2 sequestration and wastewater treatment system. J. Clean. Prod. 2019, 210, 445-458. [CrossRef]

9. Nawaz, T.; Rahman, A.; Pan, S.; Dixon, K.; Petri, B.; Selvaratnam, T. A review of landfill leachate treatment by microalgae: Current status and future directions. Processes 2020, 8, 384. [CrossRef]

10. Nagarajan, D.; Lee, D.J.; Chang, J.S. Biogas Upgrading by Microalgae: Strategies and Future Perspectives. In Microalgae Biotechnology for Development of Biofuel and Wastewater Treatment; Alam, M., Wang, Z., Eds.; Springer: Singapore, 2019. [CrossRef]

11. Rahman, A.; Agrawal, S.; Nawaz, T.; Pan, S.; Selvaratnam, T. A review of algae-based produced water treatment for biomass and biofuel production. Water 2020, 12. 2351. [CrossRef]

12. Sahu, S.K.; Mantri, V.A.; Zheng, P.; Yao, N. Chapter 1 Algae Biotechnology. Current Status, Potential and Impediments. In Encyclopedia of Marine Biotechnology; John Wiley \& Sons Ltd: Hoboken, NJ, USA, 2020. [CrossRef]

13. Vassilev, S.V.; Vassileva, C.G. Composition, properties and challenges of algae biomass for biofuel application: An overview. Fuel 2016, 181, 1-33. [CrossRef] 
14. Barsanti, L.; Gualtieri, P. Is exploitation of microalgae economically and energetically sustainable? Algal Res. 2018, 31, 107-115. [CrossRef]

15. Bhalamurugan, G.L.; Valerie, O.; Mark, L. Valuable bioproducts obtained from microalgal biomass and their commercial applications: A review. Environ. Eng. Res. 2018, 23, 229-241. [CrossRef]

16. Priyadarshani, I.; Rath, B. Commercial and industrial applications of micro algae-A review. J. Algal Biomass Util. 2012, 3, 89-100.

17. Gomez Villa, H.; Voltolina, D.; Nieves, M.; Pina, P. Biomass production and nutrient budget in outdoor cultures of Scenedesmus obliquus (chlorophyceae) in artificial wastewater, under the winter and summer conditions of Mazatla' n, Sinaloa, Mexico. Vie Et Milieu 2005, 55, 121-126.

18. Mùnoz, R.; Guieysse, B. Algal-bacterial processes for the treatment of hazardous contaminants: A review. Water Res. 2006, 40, 2799-2815. [CrossRef]

19. Chojnacka, K.; Chojnacki, A.; Gorecka, H. Biosorption of $\mathrm{Cr}^{3+}, \mathrm{Cd}^{2+}$ and $\mathrm{Cu}^{2+}$ ions by blue-green algae Spirulina sp.: Kinetics, equilibrium and the mechanism of the process. Chemosphere 2005, 59, 75-84. [CrossRef]

20. Mùnoz, R.; Köllner, C.; Guieysse, B. Biofilm photobioreactors for the treatment of industrial wastewaters. J. Hazard. Mater. 2009, 161, 29-34. [CrossRef]

21. Yewalkar, S.N.; Dhumal, K.N.; Sainis, J.K. Chromium (VI)-reducing Chlorella spp. isolated from disposal sites of paper-pulp and electroplating industry. J. Appl. Phycol. 2007, 19, 459-465.

22. Tarlan, E.; Dilek, F.B.; Yetis, U. Effectiveness of algae in the treatment of a wood-based pulp and paper industry wastewater. Bioresour. Technol. 2002, 84, 1-5. [CrossRef]

23. Acuner, E.; Dilek, F.B. Treatment of tectilon yellow 2G by Chlorella vulgaris. Process. Biochem. 2004, 39, 623-631. [CrossRef]

24. Essam, T.; Magdy, A.A.; El Tayeb, O.; Mattiasson, B.; Guieysse, B. Solar-based detoxification of phenol and p-nitrophenol by sequential $\mathrm{TiO}_{2}$ photocatalysis and photosynthetically aerated biological treatment. Water Res. 2007, 41, 1697-1704. [CrossRef] [PubMed]

25. Lima, S.A.C.; Raposo, M.F.J.; Castro, P.M.L.; Morais, R.M. Biodegradation of p-chlorophenol by a microalgae consortium. Water Res. 2004, 38, 97-102. [CrossRef] [PubMed]

26. Valderramaa, L.T.; Del Campoa, C.M.; Rodrigueza, C.M.; de-Bashan, L.E.; Bashan, Y. Treatment of recalcitrant wastewater from ethanol and citric acid production using the microalga Chlorella vulgaris and the macrophyte Lemna minuscule. Water Res. 2002, 36, 4185-4192. [CrossRef]

27. Tien, C.J. Biosorption of metal ions by freshwater algae with different surface characteristics. Process. Biochem. 2002, 38, 605-613. [CrossRef]

28. Jacob-Lopes, E.; Scoparo, C.H.G.; Queiroz, M.I.; Franco, T.T. Biotransformations of carbon dioxide in photobioreactors. Energy Convers. Manag. 2010, 51, 894-900. [CrossRef]

29. De Morais, M.G.; Costa, J.A.V. Isolation and selection of microalgae from coal fired thermoelectric power plant for biofixation of carbon dioxide. Energy Convers. Manag. 2007, 48, 2169-2173. [CrossRef]

30. Lam, M.K.; Lee, K.T.; Rahman, M.A. Current status and challenges on microalgae-based carbon capture. Int. J. Greenh. Gas Control. 2012, 10, 456-469. [CrossRef]

31. Thyagarajan, T.; Puri, M.; Vongsvivut, J.; Barrow, C.J. Evaluation of Bread Crumbs as a Potential Carbon Source for the Growth of Thraustochytrid Species for Oil and Omega-3 Production. Nutrients 2014, 6, 2104-2114. [CrossRef]

32. Ryu, B.; Kim, K.; Kim, J.; Han, J.; Yang, J. Use of organic waste from brewery industry for high-density cultivation of docosahexaenoic acid-rich microalga Aurantochytrium sp. KRS101. Bioresour. Technol. 2012, 129, 351-359. [CrossRef]

33. Unagul, P.; Assantachai, C.; Phadungruengluij, S.; Suphantharika, M.; Tanticharoen, M.; Verduyn, C. Coconut water as a medium additive for the production of docosahexaenoic acid (C22:6 n3) by Schizochytrium mangrovei Sk-02. Bioresour. Technol. 2007, 98, 281-287. [CrossRef]

34. Hong, W.; Yu, A.; Heo, S.; Oh, B.; Kim, C.; Sohn, J.; Yang, J.W.; Kondo, A.; Seo, J.W. Production of lipids containing high levels of docosahexaenoic acid from empty palm fruit bunches by Aurantiochytrium sp. KRS101. Bioprocess. Biosyst. Eng. 2013, 36, 959-963. [CrossRef] [PubMed]

35. Lin, L.; Chan, G.Y.S.; Jiang, B.L.; Lan, C.Y. Use of ammoniacal nitrogen tolerant microalgae in landfill leachate treatment. Waste Manag. 2007, 27, 1376-1382. [CrossRef] [PubMed] 
36. Jedynak, P.; Burczyk, J.; Borowski, S.; Kaszycki, P.; Hałat-Łaś, M.; Kędra, M.; Mungunkhuyag, K.; Malec, P. Use of microalgae for treatment of post-fermentation effluent from biogas production. Przemyst Chem. 2018, 97, 2106-2109.

37. Yan, C.; Zheng, Z. Performance of photoperiod and light intensity on biogas upgrade and biogas effluent nutrient reduction by the microalgae Chlorella sp. Bioresour. Technol. 2013, 139, 292-299. [CrossRef]

38. Kumar, M.; Sun, Y.; Rathour, R.; Pandey, A.; Thakur, I.S.; Tsang, D.C.W. Algae as potential feedstock for the production of biofuels and value-added products: Opportunities and challenges. Sci. Total. Environ. 2020, 716, 137116. [CrossRef]

39. Callegari, A.; Bolognesi, S.; Cecconet, D.; Capodaglio, A.G. Production technologies, current role, and future prospects of biofuels feedstocks: A state-of-the-art review. J. Crit. Rev. Environ. Sci. Technol. 2020, 50, 384-436. [CrossRef]

40. Walsh, M.J.; van Gerber Doren, L.; Sills, D.L.; Archibald, I.; Beal, C.M.; Lei, X.G.; Greene, C.H. Algal food and fuel coproduction can mitigate greenhouse gas emissions while improving land and water-use efficiency. Environ. Res. Lett. 2016, 11, 114006. [CrossRef]

41. Market Analysis Report. Algae Biofuel Market Size, Share \& Trend Analysis By Application (Transportation, Others), By Region (North America, Europe, Asia Pacific, ROW), By Country, And Segment Forecasts, 2018-2025. Grand View Research. 2017. Available online: https://www.grandviewresearch.com/industryanalysis/algae-biofuel-market (accessed on 4 August 2020).

42. Market Analysis Report. Biodiesel Market Analysis by Feedstock [Vegetable Oils (Canola Oil, Soybean Oil, Palm Oil, Corn Oil), Animal Fats (Poultry, Tallow, White Grease)], By Application (Fuel, Power Generation), And Segment Forecasts, 2018-2025. Grand View Research. 2017. Available online: https: //www.grandviewresearch.com/industry-analysis/biodiesel-market (accessed on 5 August 2020).

43. Fu, W.; Nelson, D.R.; Mystikou, A.; Daakour, S.; Salehi-Ashtiani, K. Advances in microalgal research and engineering development. Curr. Opin. Biotechnol. 2019, 59, 157-164. [CrossRef]

44. Yadav, G.; Sen, R. Sustainability of Microalgal Biorefinery: Scope, Challenges, and Opportunities. In Sustainable Energy Technology and Policies; Green Energy and, Technology, De, S., Bandyopadhyay, S., Assadi, M., Mukherjee, D., Eds.; Springer: Singapore, 2018. [CrossRef]

45. Anto, S.; Mukherjee, S.S.; Muthappa, R.; Mathimani, T.; Deviram, G.; Kumar, S.S.; Verma, T.N.; Pugazhendhi, A. Algae as green energy reserve: Technological outlook on biofuel production. Chemosphere 2020, 242, 125079. [CrossRef]

46. Borowitzka, M.A.; Vonshak, A. Scaling up microalgal cultures to commercial scale. Eur. J. Phycol 2017, 52, 407-418. [CrossRef]

47. Webster, A.; Gardner, J. Aligning technology and institutional readiness: The adoption of innovation. Technology Anal. Strateg. Manag. 2019, 31, 1229-1241. [CrossRef]

48. Ozdemir, H.I.; Pinto, C.A.; Unal, R.; Keating, C.B.; Britcher, C. Supporting technology selection via portfolio readiness level and technology forecasting. In Proceedings of the International Annual Conference of the American Society for Engineering Management; Huntsville, Philadelphia, PA, USA, 24-26 October 2019.

49. Bates, C.A.; Clausen, C. Engineering Readiness: How the TRL Figure of Merit Coordinates Technology Development. Eng. Stud. 2020, 12, 9-38. [CrossRef]

50. Paskuliakova, A.; Tonry, S.; Touzet, N. Phycoremediation of landfill leachate with chlorophytes: Phosphate a limiting factor on ammonia nitrogen removal. Water Res. 2016, 99, 180-187. [CrossRef] [PubMed]

51. Fan, Z.; Qin, L.; Zheng, W.; Meng, Q.; Shen, C.; Zhang, G. Oscillating membrane photoreactor combined with salt-tolerated Chlorella pyrenoidosa for landfill leachates treatment. Bioresour. Technol. 2018, 269, 134-142. [CrossRef] [PubMed]

52. Nair, A.T.; Senthilnathan, J.; Nagendra, S.M.S. Application of the phycoremediation process for tertiary treatment of landfill leachate and carbon dioxide mitigation. J. Water Process. Eng. 2019, 28, 322-330. [CrossRef]

53. El Ouaer, M.; Turki, N.; Kallel, A.; Halaoui, M.; Trabelsi, I.; Hassen, A. Recovery of landfill leachate as culture medium for two microalgae: Chlorella sp. and Scenedesmus sp. Environ. Dev. Sustain. 2020, 22, 2651-2671. [CrossRef]

54. Nordin, N.; Yusof, N.; Samsudin, S. Biomass production of Chlorella sp., Scenedesmus sp., and Oscillatoria sp. in nitrified landfill leachate. Waste Biomass Valoriz 2017, 8, 2301-2311. [CrossRef] 
55. Reis, C.; Loures, C.; Castro, H.; Rós, P.; Santos, J.; Filho, H.; Silva, M. Microalgae assisted bioremediation of landfill leachate using a biocoil reactor: Evaluation of operational conditions using taguchi experimental design. Br. J. Environ. Clim Chang. 2016, 6, 299-308. [CrossRef]

56. Pereira, S.F.; Goncalves, A.L.; Moreira, F.C.; Silva, T.F.; Vilar, V.J.; Pires, J.C. Nitrogen removal from landfill leachate by microalgae. Int. J. Mol. Sci. 2016, 17, 1926. [CrossRef]

57. Casazza, A.A.; Rovatti, M. Reduction of nitrogen content in landfill leachate using microalgae. Desalin. Water Treat 2018, 127, 71-74. [CrossRef]

58. Chang, H.; Quan, X.; Zhong, N.; Zhang, Z.; Lu, C.; Li, G.; Cheng, Z.; Yang, L. High-efficiency nutrients reclamation from landfill leachate by microalgae Chlorella vulgaris in membrane photobioreactor for bio-lipid production. Bioresour. Technol. 2018, 266, 374-381. [CrossRef] [PubMed]

59. Khanzada, Z.T.; Övez, S. Growing fresh water microalgae in high ammonium landfill leachate. Am. J. Mech. Appl. 2018, 6, 50-61. [CrossRef]

60. Richards, R.G.; Mullins, B.J. Using microalgae for combined lipid production and heavy metal removal from leachate. Ecol. Model. 2013, 249, 59-67. [CrossRef]

61. Dogaris, I.; Loya, B.; Cox, J.; Philippidis, G. Study of landfill leachate as a sustainable source of water and nutrients for algal biofuels and bioproducts using the microalga Picochlorum oculatum in a novel scalable bioreactor. Bioresour. Technol. 2019, 282, 18-27. [CrossRef] [PubMed]

62. Cheng, H.-X.; Tian, G.-M. Preliminary evaluation of a newly isolated microalga Scenedesmus sp. CHX1 for treating landfill leachate. In Third International Conference on Intelligent System Design and Engineering Applications; IEEE: Hong Kong, China, 2013; pp. 1057-1060.

63. Okoro, V.; Azimov, U.; Munoz, J.; Hernandez, H.H.; Phan, A.N. Microalgae cultivation and harvesting: Growth performance and use of flocculants-A review. Renew. Sustain. Energy Rev. 2019, 115, 109364. [CrossRef]

64. Lardon, L.; He'lias, A.; Sialve, B.; Steyer, J.; Bernard, O. Life-cycle assessment of biodiesel production from microalgae. Environ. Sci. Technol. 2009, 43, 6475-6481. [CrossRef]

65. Clarens, A.F.; Nassau, H.; Resurreccion, E.P.; White, M.A.; Colosi, L.M. Environmental Impacts of Algae-Derived Biodiesel and Bioelectricity for Transportation. Environ. Sci. Technol. 2011, 45, 7554-7560. [CrossRef]

66. Frank, E.D.; Han, J.; Palou-Rivera, I.; Elgowainy, A.; Wang, M.Q. User Manual for algae life-cycle analysis with GREET: Version 0.0; ANL/ESD/11-7; Argonne National Laboratory: Lemont, IL, USA, 2011.

67. Schultz-Zehden, A.; Matczak, M. (Eds.) SUBMARINER Compendium: An Assessment of Innovative and Sustainable Uses of Baltic Marine Resources; Maritime Institute in Gdansk: Gdansk, Poland, 2012.

68. ElMekawy, A.; Hegab, H.M.; Mohanakrishna, G.; Elbaz, A.F.; Bulut, M.; Pant, D. Technological advances in $\mathrm{CO}_{2}$ conversion electro-biorefinery: A step toward commercialization. Bioresour. Technol. 2016, 215, 357-370. [CrossRef]

69. Panis, G.; Carreon, J.R. Commercial astaxanthin production derived by green alga Haematococcus pluvialis: A microalgae process model and a techno-economic assessment all through production line. Algal Res. 2016, 18, 175-190. [CrossRef]

70. Su, Y.; Song, K.; Zhang, P.; Su, Y.; Cheng, J.; Chen, X. Progress of microalgae biofuel's commercialization. Renew. Sustain. Energy Rev. 2017, 74, 402-411. [CrossRef]

71. Shah, M.M.R.; Liang, Y.; Cheng, J.J.; Daroch, M. Astaxanthin-Producing Green Microalga Haematococcus pluvialis: From Single Cell to High Value Commercial Products. Front. Plant. Sci. 2016, 7, 531. [CrossRef] [PubMed]

72. Menetrez, M.Y. An overview of algae biofuel production and potential environmental impact. Environ. Sci. Technol. 2012, 46, 7073-7085. [CrossRef] [PubMed]

73. Brennan, L.; Owende, P. Biofuels from microalgae-A review of technologies for production, processing, and extractions of biofuels and co-products. Renew. Sustain. Energy Rev. 2010, 14, 557-577. [CrossRef]

74. Duong, V.T.; Li, Y.; Nowak, E.; Schenk, P.M. Microalgae Isolation and Selection for Prospective Biodiesel Production. Energies 2012, 5, 1835-1849. [CrossRef]

75. Wei, N.; Quarterman, J.; Jin, Y.S. Marine macroalgae: An untapped resource for producing fuels and chemicals. Trends Biotechnol. 2013. [CrossRef] 
76. Radakovits, R.; Jinkerson, R.E.; Fuerstenberg, S.I.; Tae, H.; Settlage, R.E.; Boore, J.L.; Posewitz, M.C. Draft genome sequence and genetic transformation of the oleaginous alga Nannochloropis gaditana. Nat. Commun. 2012, 3, 1-11. [CrossRef]

77. Dębowski, M.; Zieliński, M.; Kisielewska, M.; Kazimierowicz, J.; Dudek, M.; Świca, I.; Rudnicka, A. The Cultivation of Lipid-Rich Microalgae Biomass as Anaerobic Digestate Valorization TechnologyA Pilot-Scale Study. Processes 2020, 8, 517. [CrossRef]

78. Ganesan, R.; Manigandan, S.; Samuel, M.S.; Shanmuganathan, R.; Brindhadevi, K.; Chi, N.T.L.; Duc, P.A.; Pugazhendhi, A. A review on prospective production of biofuel from microalgae. Biotechnol. Rep. 2020, 27, e00509. [CrossRef]

79. Peng, L.; Fu, D.; Chu, H.; Wang, Z.; Qi, H. Biofuel production from microalgae: A review. Environ. Chem. Lett. 2020, 18, 285-297. [CrossRef]

80. Coimbra, R.N.; Escapa, C.; Otero, M. Comparative Thermogravimetric Assessment on the Combustion of Coal, Microalgae Biomass and Their Blend. Energies 2019, 12, 2962. [CrossRef]

81. Panahi, H.K.S.; Tabatabaei, M.; Aghbashlo, M.; Dehhaghi, M.; Rehan, M.; Nizami, A.-S. Recent updates on the production and upgrading of bio-crude oil from microalgae. Bioresour. Technol. Rep. 2019, 7, 100216. [CrossRef]

82. Feng, R.; Zaidi, A.A.; Zhang, K.; Shi, Y. Optimization of microwave pretreatment for biogas enhancement through anaerobic digestion of microalgal biomass. Period. Polytech. Chem. Eng. 2018, 63, 65-72. [CrossRef]

83. Córdova, O.; Chamy, R. Chapter 15-Microalgae to Biogas: Microbiological Communities Involved. In Microalgae Cultivation for Biofuels Production; Elsevier: London, UK; San Diego, CA, USA; Oxford, UK, 2020; pp. 227-249. [CrossRef]

84. Li, F.; Hülsey, M.J.; Yan, N.; Dai, Y.; Wang, C.-H. Co-transesterification of waste cooking oil, algal oil and dimethyl carbonate over sustainable nanoparticle catalysts. Chem. Eng. J. 2020, 405, 127036. [CrossRef] [PubMed]

85. Wang, Y.; Yang, H.; Zhang, X.; Han, F.; Tu, W.; Yang, W. Microalgal Hydrogen Production. Small Methods 2020, 4. [CrossRef]

86. Özçimen, D.; Koçer, A.T.; İnan, B.; Özer, T. Chapter 14-Bioethanol production from microalgae. In Handbook of Microalgae-Based Processes and Products; Elsevier: London, UK; San Diego, CA, USA; Cambridge, MA, USA; Oxford, UK, 2020; pp. 373-389. [CrossRef]

87. Chernova, N.I.; Kiseleva, S.V.; Larina, O.M.; Sytchev, G.A. Manufacturing gaseous products by pyrolysis of microalgal biomass. Int. J. Hydrog. Energy 2019, 45, 1569-1577. [CrossRef]

88. Lee, X.J.; Ong, H.C.; Gan, Y.Y.; Chen, W.-H.; Mahlia, T.M.I. State of art review on conventional and advanced pyrolysis of macroalgae and microalgae for biochar, bio-oil and bio-syngas production. Energy Convers. Manag. 2020, 210. [CrossRef]

89. Fawzy, M.A. Fatty Acid Characterization and Biodiesel Production by the Marine Microalga Asteromonas gracilis: Statistical Optimization of Medium for Biomass and Lipid Enhancement. Mar. Biotechnol. 2017, 19, 219-231. [CrossRef]

90. Muto, M.; Nojima, D.; Yue, L.; Kanehara, H.; Naruse, H.; Ujiro, A.; Yoshino, T.; Matsunaga, T.; Tanaka, T. Potential of water surface-floating microalgae for biodiesel production: Floating-biomass and lipid productivities. J. Biosci. Bioeng. 2016, 123, 314-318. [CrossRef]

91. Rodolfi, L.; Zittelli, G.C.; Bassi, N.; Padovani, G.; Biondi, N.; Bonini, G.; Tredici, M.R. Microalgae for oil: Strain selection, induction of lipid synthesis and outdoor mass cultivation in a low-cost photobioreactor. Biotechnol. Bioeng. 2009, 102, 100-112. [CrossRef]

92. Yuan, C.; Zheng, Y.; Zhang, W.; He, R.; Fan, Y.; Hu, G.-R.; Li, F.-L. Lipid accumulation and anti-rotifer robustness of microalgal strains isolated from Eastern China. J. Appl. Phycol. 2017, 29, 2789-2800. [CrossRef]

93. Talebi, A.F.; Mohtashami, S.K.; Tabatabaei, M.; Tohidfar, M.; Bagheri, A.; Zeinalabedini, M.; Hadavand Mirzaei, H.; Mirzajanzadeh, M.; Shafaroudi, S.M.; Bakhtiari, S. Fatty acids profiling: A selective criterion for screening microalgae strains for biodiesel production. Algal Res. 2013, 2, 258-267. [CrossRef]

94. Illman, A.M.; Scragg, A.H.; Shales, S.W. Increase in Chlorella strains calorific values when grown in low nitrogen medium. Enzyme Microb. Technol. 2000, 27, 631-635. [CrossRef]

95. Cheng, Y.; Zhou, W.G.; Gao, C.F.; Lan, K.; Gao, Y.; Wu, Q.Y. Biodiesel production from Jerusalem artichoke (Helianthus Tuberosus L.) tuber by heterotrophic microalgae Chlorella protothecoides. J. Chem. Technol. Biotechnol. 2009, 84, 777-781. [CrossRef] 
96. Xu, H.; Miao, X.L.; Wu, Q.Y. High quality biodiesel production from a microalga Chlorella protothecoides by heterotrophic growth in fermenters. J. Biotechnol. 2006, 126, 499-507. [CrossRef] [PubMed]

97. Liang, Y.; Sarkany, N.; Cui, Y. Biomass and lipid productivities of Chlorella vulgaris under autotrophic, heterotrophic and mixotrophic growth conditions. Biotechnol. Lett. 2009, 31, 1043-1049. [CrossRef] [PubMed]

98. Zhao, Y.T.; Li, D.F.; Ding, K.; Che, R.Q.; Xu, J.W.; Zhao, P.; Li, T.; Ma, H.X.; Yu, X.Y. Production of biomass and lipids by the oleaginous microalgae Monoraphidium sp. QLY-1 through heterotrophic cultivation and photo-chemical modulator induction. Bioresour. Technol. 2016, 211, 669-676. [CrossRef] [PubMed]

99. Mandal, S.; Mallick, N. Microalga Scenedesmus obliquus as a potential source for biodiesel production. Appl. Microbiol. Biotechnol. 2009, 84, 281-291. [CrossRef]

100. Byreddy, A.R.; Gupta, A.; Barrow, C.J.; Puri, M. Comparison of cell disruption methods for improving lipid extraction from thraustochytrid strains. Mar. Drugs 2015, 13, 5111-5127. [CrossRef]

101. Kusumaningtyas, P.; Nurbaiti, S.; Suantika, G.; Amran, M.B.; Nurachman, Z. Enhanced oil production by the tropical marine diatom Thalassiosira sp. cultivated in outdoor photobioreactors. Appl. Biochem. Biotechnol. 2017, 182, 1605-1618. [CrossRef]

102. Chen, C.; Lee, M.; Dong, C.; Kit, Y.; Chang, J. Enhanced production of microalgal lipids using a heterotrophic marine microalga Thruastochytrium sp. BM2. Biochem. Eng. J. 2020, 154, 107429. [CrossRef]

103. Uba, M.O.; Duabe, K.C.P.; Biene, M.A.C.M.; Ortiz, M.K.C.R.; Bennett, R.M.; Dedeles, G.R. Growth and fatty acid profile of Thraustochytrium sp. CR01 using different sugar substitutes. Philippine J. Sci. 2016, 145, 365-371.

104. Shene, C.; Garces, M.; Vergara, D.; Pena, J.; Claverol, S.; Rubilar, M.; Leyton, A. Production of lipids and proteome variation in a chilean Thraustochytrium striatum strain cultured under different growth conditions. Mar. Biotechnol. 2019, 21, 99-110. [CrossRef] [PubMed]

105. Patil, R.A.; Kausley, S.B.; Joshi, S.M.; Pandit, A.B. Chapter 27-Process intensification applied to microalgae-based processes and products. In Handbook of Microalgae-Based Processes and Products; Elsevier: London, UK; San Diego, CA, USA; Cambridge, MA, USA; Oxford, UK, 2020; pp. 737-769. [CrossRef]

106. Nagappan, S.; Devendran, S.; Tsai, P.-C.; Dahms, H.-U.; Ponnusamy, V.K. Potential of two-stage cultivation in microalgae biofuel production. Fuel 2019, 252, 339-349. [CrossRef]

107. Fazal, T.; Mushtaq, A.; Rehman, F.; Khan, A.U.; Rashid, N.; Farooq, W.; Rehman, M.S.U.; Xu, J. Bioremediation of textile wastewater and successive biodiesel production using microalgae. Renew. Sustain. Energy Rev. 2018, 82, 3107-3126. [CrossRef]

108. Zhang, L.; Cheng, J.; Pei, H.; Pan, J.; Jiang, L.; Hou, Q. Cultivation of microalgae using anaerobically digested ef fl uent from kitchen waste as a nutrient source for biodiesel production. Renew. Energy 2018, 115, $276-287$. [CrossRef]

109. Sati, H.; Mitra, M.; Mishra, S.; Baredar, P. Microalgal lipid extraction strategies for biodiesel production: A review. Algal Res. 2019, 38. [CrossRef]

110. Menegazzo, M.L.; Fonseca, G.G. Biomass recovery and lipid extraction processes for microalgae biofuels production: A review. Renew. Sustain. Energy Rev. 2019, 107, 87-107. [CrossRef]

111. Lee, S.Y.; Khoiroh, I.; Vo, D.N.; Kumar, S.; Loke, P. Show Techniques of lipid extraction from microalgae for biofuel production: A review. Environ. Chem. Lett. 2020, 1-21. [CrossRef]

112. Ranjith Kumar, R.; Hanumantha Rao, P.; Arumugam, M. Lipid extraction methods from microalgae: A comprehensive review. Front. Energy Res. 2015, 2, 61. [CrossRef]

113. Kumar, V.; Arora, N.; Nanda, M.; Pruthi, V. Different Cell Disruption and Lipid Extraction Methods from Microalgae for Biodiesel Production. In Microalgae Biotechnology for Development of Biofuel and Wastewater Treatment; Alam, M., Wang, Z., Eds.; Springer: Singapore, 2019. [CrossRef]

114. Choudhary, P.; Assemany, P.P.; Naaz, F.; Bhattacharya, A.; Castro, J.S.; Couto, E.A.; Calijuri, M.L.; Pant, K.K.; Malik, A. A review of biochemical and thermochemical energy conversion routes of wastewater grown algal biomass. Sci. Total. Environ. 2020, 726, 137961. [CrossRef]

115. Ren, J.; Liu, Y.-L.; Zhao, X.-Y.; Cao, J.-P. Biomass thermochemical conversion: A review on tar elimination from biomass catalytic gasification. J. Energy Inst. 2020, 93, 1083-1098. [CrossRef]

116. Clark, J.; Deswarte, F. Introduction to chemicals from biomass. In Wiley Series in Renewable Resources; Stevens, C.V., Ed.; John Wiley \& Sons: Hoboken, NJ, USA, 2008. 
117. Radenahmad, N.; Azad, A.T.; Saghir, M.; Taweekun, J.; Bakar, M.S.A.; Reza, M.S.; Azad, A.K. A review on biomass derived syngas for SOFC based combined heat and power application. Renew. Sustain. Energy Rev. 2020, 119, 109560. [CrossRef]

118. Kousheshi, N.; Yari, M.; Paykani, A.; Saberi Mehr, A.; de la Fuente, G.F. Effect of Syngas Composition on the Combustion and Emissions Characteristics of a Syngas/Diesel RCCI Engine. Energies 2020, 13, 212. [CrossRef]

119. Hirano, A.; Hon-Nami, K.; Kunito, S.; Hada, M.; Ogushi, Y. Temperature effect on continuous gasification of microalgal biomass: Theoretical yield of methanol production and its energy balance. Catal. Today 1998, 45, 399-404. [CrossRef]

120. Minowa, T.; Sawayama, S. A novel microalgal system for energy production with nitrogen cycling. Fuel 1999, 78, 1213-1215. [CrossRef]

121. Patil, V.; Tran, K.-Q.; Giselrød, H.R. Towards sustainable production of biofuels from microalgae. Int. J. Mol. Sci. 2008, 9, 1188-1195. [CrossRef]

122. Ong, H.C.; Chen, W.-H.; Farooq, A.; Gan, Y.Y.; Lee, K.T.; Ashokkumar, V. Catalytic thermochemical conversion of biomass for biofuel production: A comprehensive review. Renew. Sustain. Energy Rev. 2019, 113, 109266. [CrossRef]

123. McKendry, P. Energy production from biomass (part 2): Conversion technologies. Bioresour. Technol. 2002, 83, 47-54. [CrossRef]

124. Dote, Y.; Sawayama, S.; Inoue, S.; Minowa, T.; Yokoyama, S.-Y. Recovery of liquid fuel from hydrocarbon-rich microalgae by thermochemical liquefaction. Fuel 1994, 73, 1855-1857. [CrossRef]

125. Minowa, T.; Yokoyama, S.-Y.; Kishimoto, M.; Okakura, T. Oil production from algal cells of Dunaliella tertiolecta by direct thermochemical liquefaction. Fuel 1995, 74, 1735-1738. [CrossRef]

126. Aravind, S.; Kumar, P.S.; Kumar, N.S.; Siddarth, N. Conversion of green algal biomass into bioenergy by pyrolysis. A review. Environ. Chem. Lett. 2020, 18, 829-849. [CrossRef]

127. Miao, X.L.; Wu, Q.Y. High yield bio-oil production from fast pyrolysis by metabolic controlling of Chlorella protothecoides. J. Biotechnol. 2004, 110, 85-93. [CrossRef] [PubMed]

128. Miao, X.; Wu, Q.; Yang, C. Fast pyrolysis of microalgae to produce renewable fuels. J. Anal. Appl. Pyrolysis 2004, 71, 855-863. [CrossRef]

129. Yang, X.; Wang, X.; Zhao, B.; Li, Y. Simulation model of pyrolysis biofuel yield based on algal components and pyrolysis kinetics. Bioenerg. Res. 2014, 7, 1293-1304. [CrossRef]

130. Gong, X.; Zhang, B.; Zhang, Y.; Huang, Y.; Xu, M. Investigation on Pyrolysis of Low Lipid Microalgae Chlorella vulgaris and Dunaliella salina. Energy Fuel 2014, 28, 95-103. [CrossRef]

131. Grierson, S.; Strezov, V.; Ellem, G.; Mcgregor, R.; Herbertson, J. Thermal characterisation of microalgae under slow pyrolysis conditions. J. Anal. Appl. Pyrolysis 2009, 85, 118-123. [CrossRef]

132. Peng, W.; Wu, Q.; Tu, P. Effects of temperature and holding time on production of renewable fuels from pyrolysis of Chlorella protothecoides. J. Appl. Phycol. 2000, 12, 147-152. [CrossRef]

133. Maddi, B.; Viamajala, S.; Varanasi, S. Comparative study of pyrolysis of algal biomass from natural lake blooms with lignocellulosic biomass. Bioresour. Technol. 2011, 102, 11018-11026. [CrossRef]

134. Hu, Z.; Zheng, Y.; Yan, F.; Xiao, B.; Liu, S. Bio-oil production through pyrolysis of blue-green algae blooms (BGAB): Product distribution and bio-oil characterization. Energy 2013, 52, 119-125. [CrossRef]

135. Jena, U.; Das, K.C. Comparative evaluation of thermochemical liquefaction and pyrolysis for bio-oil production from microalgae. Energy Fuel 2011, 25, 5472-5482. [CrossRef]

136. Demirbas, A. Oily products from mosses and algae via pyrolysis. Energy Sources Part A-Recover. Utilization Environ. Effects 2006, 28, 933-940. [CrossRef]

137. Li, F.; Srivatsa, S.C.; Bhattacharya, S. A review on catalytic pyrolysis of microalgae to high-quality bio-oil with low oxygeneous and nitrogenous compounds. Renew. Sustain. Energy Rev. 2019, 108, 481-497. [CrossRef]

138. Hirano, A.; Ueda, R.; Hirayama, S.; Ogushi, Y. $\mathrm{CO}_{2}$ fixation and ethanol production with microalgal photosynthesis and intracellular anaerobic fermentation. Energy 1997, 22, 137-142. [CrossRef]

139. Ueno, Y.; Kurano, N.; Miyachi, S. Ethanol production by dark fermentation in the marine green alga, Chlorococcum littorale. J. Ferment. Bioeng. 1998, 86, 38-43. [CrossRef]

140. Lee, S.Y.; Sankaran, R.; Chew, K.W.; Tan, C.H.; Krishnamoorthy, R.; Chu, D.-T.; Show, P.-L. Waste to bioenergy: A review on the recent conversion technologies. BMC Energy 2019, 1, 4. [CrossRef]

141. Choi, S.P.; Nguyen, M.T.; Sim, S.J. Enzymatic pretreatment of Chlamydomonas reinhardtii biomass for ethanol production. Bioresour. Technol. 2010, 101, 5330-5336. [CrossRef] [PubMed] 
142. Zhou, N.; Zhang, Y.; Wu, X.; Gong, X.; Wang, Q. Hydrolysis of Chlorella biomass for fermentable sugars in the presence of $\mathrm{HCl}$ and $\mathrm{MgCl}_{2}$. Bioresour. Technol. 2011, 102, 10158-10161. [CrossRef]

143. Cheng, Y.S.; Zheng, Y.; Labavitch, J.M.; VanderGheynst, J.S. Virus infection of Chlorella variabilis and enzymatic saccharification of algal biomass for bioethanol production. Bioresour. Technol. 2013, 137, 326-331. [CrossRef]

144. Lee, S.; Oh, Y.; Kim, D.; Kwon, D.; Lee, C.; Lee, J. Converting carbohydrates extracted from marine algae into ethanol using various ethanolic Escherichia coli strains. Appl. Biochem. Biotechnol. 2011, 164, 878-888. [CrossRef]

145. Ho, S.H.; Huang, S.W.; Chen, C.Y.; Hasunuma, T.; Kondo, A.; Chang, J.S. Bioethanol production using carbohydrate-rich microalgae biomass as feedstock. Bioresour. Technol. 2013, 135, 191-198. [CrossRef]

146. Harun, R.; Jason, W.S.Y.; Cherrington, T.; Danquah, M.K. Exploring alkaline pre-treatment of microalgal biomass for bioethanol production. Appl. Energy 2011, 88, 3464-3467. [CrossRef]

147. Harun, R.; Danquah, M.K.; Forde, G.M. Microalgal biomass as a fermentation feedstock for bioethanol production. J. Chem. Technol. Biotechnol. 2010, 85, 199-203. [CrossRef]

148. Kim, H.M.; Oh, C.H.; Bae, H.-J. Comparison of red microalgae (Porphyridium cruentum) culture conditions for bioethanol production. Bioresour. Technol. 2017, 233, 44-50. [CrossRef] [PubMed]

149. Ghirardi, M.L.; Zhang, L.; Lee, J.W.; Flynn, T.; Seibert, M.; Greenbaum, E.; Melis, A. Microalgae: A green source of renewable $\mathrm{H}_{2}$. Trends Biotechnol. 2000, 18, 506-511. [CrossRef]

150. Saratale, G.D.; Saratale, R.G.; Banu, J.R.; Chang, J.-S. Biohydrogen Production From Renewable Biomass Resources. In Biohydrogen; Elsevier: Amsterdam, The Netherlands, 2019; pp. 247-277.

151. Veras, T.S.; Mozer, T.S.; César, A.S. Hydrogen: Trends, production and characterization of the main process worldwide. Int. J. Hydrogen Energy 2017, 42, 2018-2033. [CrossRef]

152. Razu, M.H.; Hossain, F.; Khan, M. Advancement of Bio-hydrogen Production from Microalgae. In Microalgae Biotechnology for Development of Biofuel and Wastewater Treatment; Springer: Gateway East, Singapore, 2019; pp. 423-462.

153. Grechanik, V.; Romanova, A.; Naydov, I.; Tsygankov, A. Photoautotrophic cultures of Chlamydomonas reinhardtii: Sulfur deficiency, anoxia, and hydrogen production. Photosynth. Res. 2020, 143, 275-286. [CrossRef]

154. Fakhimi, N.; Tavakoli, O. Improving hydrogen production using co-cultivation of bacteria with Chlamydomonas reinhardtii microalga. Mater. Sci. Energy Technol. 2019, 2, 1-7. [CrossRef]

155. Skjanes, K.; Knutsen, G.; Källqvist, T.; Lindblad, P. $\mathrm{H}_{2}$ production from marine and freshwater species of green algae during sulfur deprivation and considerations for bioreactor design. Int. J. Hydrog. Energy 2008, 33, 511-521. [CrossRef]

156. Guan, Y.; Deng, M.; Yu, X.; Zhang, W. Two-stage photo-biological production of hydrogen by marine green alga Platymonas subcordiformis. Biochem. Eng. J. 2004, 19, 69-73. [CrossRef]

157. Guo, Z.; Chen, Z.; Lu, H.; Fu, Y.; Yu, X.; Zhang, W. Sustained hydrogen photoproduction by marine green algae platymonas subcordiformis integrated with in situ hydrogen consumption by an alkaline fuel cell system. J. Biotechnol. 2008, 136, 558-576. [CrossRef]

158. Tamburic, B.; Zemichael, F.W.; Maitland, G.C.; Hellgardt, K. Parameters affecting the growth and hydrogen production of the green alga Chlamydomonas reinhardtii. Int. J. Hydrog. Energy 2011, 36, 7872-7876. [CrossRef]

159. Oncel, S.; Sukan, F.V. Effect of light intensity and the light: Dark cycles on the long term hydrogen production of Chlamydomonas reinhardtii by batch cultures. Biomass Bioenergy 2011, 35, 1066-1074. [CrossRef]

160. Song, W.; Rashid, N.; Choi, W.; Lee, K. Biohydrogen production by immobilized Chlorella sp. using cycles of oxygenic photosynthesis and anaerobiosis. Bioresour. Technol. 2011, 102, 8676-8681. [CrossRef] [PubMed]

161. Guo, Z.; Chen, Z.; Zhang, W.; Yu, X.; Jin, M. Improved hydrogen photoproduction regulated by carbonylcyanide $\mathrm{m}$-chlorophenylhrazone from marine green alga Platymonas subcordiformis grown in $\mathrm{CO}_{2}$-supplemented air bubble column bioreactor. Biotechnol. Lett. 2008, 30, 877-883. [CrossRef]

162. Ji, C.F.; Legrand, J.; Pruvost, J.; Chen, Z.A.; Zhang, W. Characterization of hydrogen production by Platymonas Subcordiformis in torus photobioreactor. Int. J. Hydrog. Energy 2010, 35, 7200-7205. [CrossRef]

163. Ji, C.F.; Yu, X.J.; Chen, Z.A.; Xue, S.; Legrand, J.; Zhang, W. Effects of nutrient deprivation on biochemical compositions and photo-hydrogen production of Tetraselmis subcordiformis. Int. J. Hydrog. Energy 2011, 36, 5817-5821. [CrossRef] 
164. Chew, K.W.; Yap, J.Y.; Show, P.L.; Suan, N.H.; Juan, J.C.; Ling, T.C.; Lee, D.-J.; Chang, J.-S. Microalgae biorefinery: High value products perspectives. Bioresour. Technol. 2017, 229, 53-62. [CrossRef]

165. Sialve, B.; Bernet, N.; Bernard, O. Anaerobic digestion of microalgae as a necessary step to make microalgal biodiesel. Sustainable. Biotechnol. Adv. 2009, 27, 409-416. [CrossRef]

166. Olguin, E.J. The cleaner production strategy applied to animal production. In Environmental Biotechnology and Cleaner Bioprocesses; Olguín, E.J., Sánchez, G., Hemández, E., Eds.; Taylor and Francis: London, UK, 2000; pp. 107-121.

167. Yen, H.-W.; Brune, D.E. Anaerobic co-digestion of algal sludge and waste paper to produce methane. Bioresour. Technol. 2007, 98, 130-134. [CrossRef]

168. Klocke, M.; Mahnert, P.; Mundt, K.; Souidi, K.; Linke, B. Microbial community analysis of a biogas-producing completely stirred tank reactor fed continuously with fodder beet silage as mono-substrate. Syst. Appl. Microbiol. 2007, 30, 139-151. [CrossRef]

169. Schlüter, A.; Bekel, T.; Diaz, N.N.; Dondrup, M.; Eichenlaub, R.; Gartemann, K.H.; Krahn, I.; Krause, L.; Kromeke, H.; Kruse, O; et al. The metagenome of a biogas-producing microbial community of a production-scale biogas plant fermenter analysed by the 454-pyrosequencing technology. J. Biotechnol. 2008, 136, 77-90. [CrossRef] [PubMed]

170. Mussgnug, J.H.; Klassen, V.; Schlüter, A.; Kruse, O. Microalgae as substrates for fermentative biogas production in a combined biorefinery concept. J. Biotechnol. 2010, 150, 51-56. [CrossRef] [PubMed]

171. Ciudad, G.; Rubilar, O.; Azocar, L.; Toro, C.; Cea, M.; Torres, A.; Ribera, A.; Navia, R. Performance of an enzymatic extract in Botrycoccus braunii cell wall disruption. J. Biosci. Bioeng. 2014, 117, 75-80. [CrossRef] [PubMed]

172. Frigon, J.-C.; Matteau-Lebrun, F.; Hamani Abdou, R.; McGinn, P.J.; O’Leary, S.J.B.; Guiot, S.R. Screening microalgae strains for their productivity in methane following anaerobic digestion. Appl. Energy 2013, 108, 100-107. [CrossRef]

173. Prajapati, S.K.; Malik, A.; Vijay, V.K. Comparative evaluation of biomass production and bioenergy generation potential of Chlorella spp. through anaerobic digestion. Appl. Energy 2014, 114, 790-797. [CrossRef]

174. Ayala-Parra, P.; Liu, Y.; Field, J.A.; Sierra-Alvarez, R. Nutrient recovery and biogas generation from the anaerobic digestion of waste biomass from algal biofuel production. Renew. Energy 2017, 108, 410-416. [CrossRef]

175. Polakovičová, G.; Kušnír, P.; Nagyová, S.; Mikulec, J. Process integration of algae production and anaerobic digestion. Chem. Eng. Trans. 2012, 29, 1129-1134.

176. Prajapati, S.K.; Kaushik, P.; Malik, A.; Vijay, V.K. Phycoremediation and biogas potential of native algal isolates from soil and wastewater. Bioresour. Technol. 2013, 135, 232-238. [CrossRef]

177. Vergara-Fernández, A.; Vargas, G.; Alarcón, N.; Velasco, A. Evaluation of marine algae as a source of biogas in a two-stage anaerobic reactor system. Biomass Bioenergy 2008, 32, 338-344. [CrossRef]

178. Buxy, S.; Diltz, R.; Pullammanappallil, P. Biogasification of marine algae Nannochloropsis oculata. In Materials Challenges in Alternative and Renewable Energy II: Ceramic Transactions; John Wiley \& Sons, Inc.: Hoboken, NJ, USA, 2012; pp. 59-67.

179. Park, S.; Li, Y. Evaluation of methane production and macronutrient degradation in the anaerobic co-digestion of algae biomass residue and lipid waste. Bioresour. Technol. 2012, 111, 42-48. [CrossRef]

180. Campbell, J.; Lobell, D.; Field, C. Greater transportation energy and GHG offsets from bioelectricity than ethanol. Science 2009, 324, 1055-1057. [CrossRef] [PubMed]

181. Börjesson, P.; Berglund, M. Environmental systems analysis of biogas systems -part I: Fuel-cycle emissions. Biomass Bioenergy 2006, 30, 469-485. [CrossRef]

182. Ubando, A.T.; Rivera, D.R.T.; Chen, W.H.; Culaba, A.B. A comprehensive review of life cycle assessment (LCA) of microalgal and lignocellulosic bioenergy products from thermochemical processes. Bioresour. Technol. 2019, 291, 121837. [CrossRef]

183. Ubando, A.T.; Felix, C.B.; Chen, W.-H. Biorefineries in circular bioeconomy: A comprehensive review. Bioresour. Technol. 2020, 299, 122585. [CrossRef] [PubMed]

184. Chandra, R.; Iqbal, H.M.N.; Vishal, G.; Lee, H.S.; Nagra, S. Algal biorefinery: A sustainable approach to valorize algal-based biomass towards multiple product recovery. Bioresour. Technol. 2019, 278, 346-359. [CrossRef] [PubMed] 
185. Kisielewska, M.; Zieliński, M.; Dębowski, M.; Kazimierowicz, J.; Romanowska-Duda, Z.; Dudek, M. Effectiveness of Scenedesmus sp. Biomass Grow and Nutrients Removal from Liquid Phase of Digestates. Energies 2020, 13, 1432. [CrossRef]

186. Mohan, S.V.; Hemalatha, M.; Chakraborty, D.; Chatterjee, S.; Ranadheer, P.; Kona, R. Algal biorefinery models with self-sustainable closed loop approach: Trends and prospective for blue-bioeconomy. Bioresour. Technol. 2019, 295, 122128. [CrossRef]

187. Mishra, S.; Roy, M.; Mohanty, K. Microalgal bioenergy production under zero-waste biorefinery approach: Recent advances and future perspectives. Bioresour. Technol. 2019, 292, 122008. [CrossRef]

188. Metsoviti, M.N.; Papapolymerou, G.; Karapanagiotidis, I.T.; Katsoulas, N. Comparison of Growth Rate and Nutrient Content of Five Microalgae Species Cultivated in Greenhouses. Plants 2019, 8, 279. [CrossRef]

189. Aziz, M.M.A.; Kassim, A.K.; Shokravi, Z.; Jakarni, F.M.; Liu, H.Y.; Zaini, N. Two-stage cultivation strategy for simultaneous increases in growth rate and lipid content of microalgae: A review. Renew. Sustain. Energy Rev. 2020, 119, 109621. [CrossRef]

190. Sánchez-Bayo, A.; Morales, V.; Rodríguez, R.; Vicente, G.; Bautista, L.F. Cultivation of microalgae and cyanobacteria: Effect of operating conditions on growth and biomass composition. Molecules 2020, 25, 2834. [CrossRef] [PubMed]

191. Neofotis, P.; Huang, A.; Sury, K.; Chang, W.; Joseph, F.; Gabr, A.; Twary, S.; Qiu, W.; Holguine, O.; Polle, J.E.W. Characterization and classification of highly productive microalgae strains discovered for biofuel and bioproduct generation. Algal Res. 2016, 15, 164-178. [CrossRef]

192. Li, P.; Sakuragi, K.; Makino, H. Extraction Techniques in Sustainable Biofuel Production: A Concise Review. Fuel Process. Technol. 2019, 193, 295-303. [CrossRef]

193. Piasecka, A.; Nawrocka, A.; Wiącek, D.; Krzemińska, J. Agro-industrial by-product in photoheterotrophic and mixotrophic culture of Tetradesmus obliquus: Production of $\omega 3$ and $\omega 6$ essential fatty acids with biotechnological importance. Sci Rep. 2020, 10, 1-11. [CrossRef]

194. Saad, M.G.; Dosoky, N.S.; Zoromba, M.S.; Shafik, H.M. Algal Biofuels: Current Status and Key Challenges. Energies 2019, 12, 1920. [CrossRef]

195. Patel, A.K.; Young, Y.; Sang, C.; Sim, J. Emerging prospects of mixotrophic microalgae: Way forward to sustainable bioprocess for environmental remediation and cost-effective biofuels. Bioresour. Technol. 2020, 300, 122741. [CrossRef] [PubMed]

196. Chojnacka, K.; Marquez-Rocha, F.J. Kinetic and stoichiometric relationships of the energy and carbon metabolism in the culture of microalgae. Biotechnology 2004, 3, 21-34. [CrossRef]

197. Ogbonna, J.C.; Ichige, E.; Tanaka, H. Regulating the ratio of photoautotrophic to heterotrophic metabolic activities in photoheterotrophic culture of Euglena gracilis and its application to alpha-tocopherol production. Biotechnol. Lett. 2002, 24, 953-958. [CrossRef]

198. Huang, G.H.; Chen, F.; Wei, D.; Zhang, X.W.; Chen, G. Biodiesel production by microalgal biotechnology. Appl. Energy 2010, 87, 38-46. [CrossRef]

199. Yoo, C.; Jun, S.Y.; Lee, J.Y.; Ahn, C.Y.; Oh, H.M. Selection of microalgae for lipid production under high levels carbon dioxide. Bioresour. Technol. 2010, 101, 71-74. [CrossRef]

200. Chiu, S.-Y.; Kaom, C.-J.; Chen, C.-H.; Kuan, T.-C.; Ong, S.-C.; Lin, C.-S. Reduction of $\mathrm{CO}_{2}$ by a high-density culture of Chlorella sp. in a semicontinuous photobioreactor. Bioresour. Technol. 2008, 99, 3389-3396. [CrossRef]

201. Morales-Sánchez, D.; Martinez-Rodriguez, O.A.; Martinez, A. Heterotrophic cultivation of microalgae: Production of metabolites of commercial interest. J. Chem. Technol. Biotechnol. 2016, 92, 925-936. [CrossRef]

202. De Swaaf, M.; Sijtsma, L.; Pronk, J. High-cell-density fed-batch cultivation of the docosahexaenoic acid producing microalga Crypthecodinium cohnii. Biotechnol. Bioeng. 2003, 81, 666-672. [CrossRef] [PubMed]

203. Kuei-Ling, Y.; Jo-Shu, C. Effects of cultivation conditions and media composition on cell growth and lipid productivity of indigenous microalga Chlorella vulgaris ESP-31. Bioresour. Technol. 2012, 105, 120-127.

204. Caporgno, M.P.; Haberkorn, I.; Böcker, L.; Mathys, A. Cultivation of Chlorella protothecoides under different growth modes and its utilisation in oil/water emulsions. Bioresour. Technol. 2019, 288, 121476. [CrossRef] [PubMed]

205. Sim, S.J.; Joun, J.; Hong, M.E.; Patel, A.K. Split mixotrophy: A novel cultivation strategy to enhance the mixotrophic biomass and lipid yields of Chlorella protothecoides. Bioresour. Technol. 2019, 291, 121820. [CrossRef] [PubMed] 
206. Shen, X.; Qin, Q.; Yan, S.; Huang, J.L.; Liu, K.; Zhou, S.-B. Biodiesel production from Chlorella vulgaris under nitrogen starvation in autotrophic, heterotrophic, and mixotrophic cultures. J. Appl. Phycol. 2019, 31, 1589-1596. [CrossRef]

207. Li, T.; Kirchhoff, H.; Gargouri, M.; Feng, J.; Cousins, A.B.; Pienkos, P.T.; Gang, D.R.; Chen, S. Assessment of photosynthesis regulation in mixotrophically cultured microalga Chlorella sorokiniana. Algal Res. 2016, 19, 30-38. [CrossRef]

208. Zheng, Y.; Chi, Z.; Lucker, B.; Chen, S. Two-stage heterotrophic and phototrophic culture strategy for algal biomass and lipid production. Bioresour. Technol. 2012, 103, 484-488. [CrossRef]

209. Li, T.; Zheng, Y.; Yu, L.; Chen, S. Mixotrophic cultivation of a Chlorella sorokiniana strain for enhanced biomass and lipid production. Biomass Bioenergy 2014, 66, 204-213. [CrossRef]

210. Pang, N.; Gu, X.; Chen, S.; Kirchhoff, H.; Lei, H.; Rojec, S. Exploiting mixotrophy for improving productivities of biomass and co-products of microalgae. Renew. Sustain. Energy Rev. 2019, 112, 450-460. [CrossRef]

211. Chen, Y.H.; Walker, T.H. Biomass and lipid production of heterotrophic microalgae Chlorella protothecoides by using biodiesel-derived crude glycerol. Biotechnol. Lett. 2011, 33, 1973. [CrossRef] [PubMed]

212. Zuccaro, G.; Yousuf, A.; Pollio, A.; Steyer, J.-P. Microalgae Cultivation Systems. In Microalgae Cultivation for Biofuels Production; Elsevier: London, UK; San Diego, CA, USA; Cambridge, MA, USA; Oxford, UK, 2020; pp. 11-29. [CrossRef]

213. Cezare-Gomes, E.A.; del Mejia-da-Silva, L.C.; Pérez-Mora, L.S.; Matsudo, M.C.; Ferreira-Camargo, L.S.; Singh, A.K.; de Carvalho, J.C.M. Potential of Microalgae Carotenoids for Industrial Application. Appl. Biochem. Biotechnol. 2019, 188, 602-634. [CrossRef] [PubMed]

214. Zhang, Y.; Su, H.; Zhong, Y.; Zhang, C.; Shen, Z.; Sang, W.; Yan, G.; Zhou, X. The effect of bacterial contamination on the heterotrophic cultivation of Chlorella pyrenoidosa in wastewater from the production of soybean products. Water Res. 2012, 46, 5509-5516. [CrossRef] [PubMed]

215. Marudhupandia, T.; Sathishkumara, R.; Kumara, T.T.A. Heterotrophic cultivation of Nannochloropsis salina for enhancing biomass and lipid production. Biotechnol. Rep. 2016, 10, 8-16. [CrossRef] [PubMed]

216. Chandra, R.; Arora, S.; Rohit, M.V.; Mohan, S.V. Lipid metabolism in response to individual short chain fatty acids during mixotrophic mode of microalgal cultivation: Influence on biodiesel saturation and protein profile. Bioresour. Technol. 2015, 188, 169-176. [CrossRef]

217. Mata, T.M.; Martins, A.A.; Caetano, N.S. Microalgae for biodiesel production and other applications: A review. Renew. Sustain. Energy Rev. 2010, 14, 217-232. [CrossRef]

218. Bhatnagar, A.; Chinnasamy, S.; Singh, M.; Das, K.C. Renewable biomass production by mixotrophic algae in the presence of various carbon sources and wastewaters. Appl. Energy 2011, 88, 3425-3431. [CrossRef]

219. Yu, H.F.; Jia, S.R.; Dai, Y.J. Growth characteristics of the cyanobacterium Nostoc flagelliformein photoautotrophic, mixotrophic and heterotrophic cultivation. J. Appl. Phycol. 2009, 21, 127-133. [CrossRef]

220. Bailey, R.; DiMasi, D.; Hansen, J.; Mirrasoul, P.; Ruecker, C.; Kaneko, T.; Barclay, W. Enhanced Production of Lipids Containing Polyenoic Fatty Acid by Very High Density Cultures of Eukaryotic Microbes in. Fermentors Patent No.: US 6,607,900 B2, 19 August 2003.

221. Anand, P.; Saxena, R.K. A comparative study of solvent-assisted pretreatment of biodiesel derived crude glycerol on growth and 1,3-propanediol production from Citrobacter freundii. New Biotechnol. 2011, 29, 199-205. [CrossRef]

222. Jiang, Y.; Yoshida, T.; Quigg, A. Photosynthetic performance, lipid production and biomass composition in response to nitrogen limitation in marine microalgae. Plant Physiol. Biochem. 2012, 54, 70-77. [CrossRef] [PubMed]

223. Reverdatto, S.; Beilinson, V.; Nielsen, N.C. A multisubunit acetyl coenzyme A carboxylase fromsoybean. Plant Physiol. 1999, 119, 961-978. [CrossRef] [PubMed]

224. Chen, J.W.; Liu, W.J.; Hu, D.X.; Wang, X.; Balamurugan, S.; Alimujiang, A.; Yang, W.D.; Liu, J.S.; Li, H.Y. Identification of a malonyl CoA-acyl carrier protein transacylase and its regulatory role infatty acid biosynthesis in oleaginous microalga Nannochloropsis oceanic. Biotechnol. Appl. Biochem. 2016, 64, 620-626. [CrossRef]

225. Fan, J.; Andre, C.; Xu, C. A chloroplast pathway for the de novo biosynthesis of triacylglycerol inChlamydomonas reinhardtii. FEBS Lett. 2011, 585, 1985-1991. [CrossRef] [PubMed] 
226. Wan, L.; Han, J.; Sang, M.; Li, A.; Wu, H.; Yin, S.; Zhang, C. De novo transcriptomic analysis of anoleaginous microalga: Pathway description and gene discovery for production of next-generationbiofuels. PLOS ONE 2012, 7, e35142. [CrossRef] [PubMed]

227. Lenka, S.K.; Carbonaro, N.; Park, R.; Miller, S.M.; Thorpe, I.; Li, Y. Current advances in molecular, biochemical, and computational modeling analysis of microalgal triacylglycerol biosynthesis. Biotechnol. Adv. 2016, 34, 1046-1063. [CrossRef] [PubMed]

228. Show, K.-Y.; Yan, Y.-G.; Lee, D.-J. Biohydrogen production from algae: Perspectives, challenges, and prospects. In Biofuels from Algae, 2nd ed.; Elsevier: Amsterdam, The Netherlands; Oxford, UK; Cambridge, MA, USA, 2019; pp. 325-343. [CrossRef]

229. Dasgupta, C.N.; Gilbert, J.J.; Lindblad, P.; Heidorn, T.; Borgvang, S.A.; Skjanes, K.; Das, D. Recent trends on the development of photobiological processes and photobioreactors for the improvement of hydrogen production. Int. J. Hydrog. Energy 2010, 35, 10218-10238. [CrossRef]

230. Miyake, J.; Miyake, M.; Asada, Y. Biotechnological hydrogen production: Research for efficient light energy conversion. J. Biotechnol. 1999, 70, 89-101. [CrossRef]

231. Ni, F.M.; Leung, D.Y.C.; Leung, M.K.H.; Sumathy, K. An overview of hydrogen production from biomass. Fuel Process. Technol. 2006, 87, 461-472. [CrossRef]

232. Akhlaghi, N.; Najafpour-Darzi, G. A comprehensive review on biological hydrogen production. Int. J. Hydrog. Energy 2020, 45, 22492-22512. [CrossRef]

233. Das, D.; Veziroglu, T.N. Hydrogen production by biological processes: A survey of literature. Int. J. Hydrog. Energy 2001, 26, 13-28. [CrossRef]

234. Kim, D.H.; Kim, M.S. Hydrogenases for biological hydrogen production. Bioresour. Technol. 2011, 102, 8423-8431. [CrossRef] [PubMed]

235. Chen, W.-H.; Lin, B.-J.; Huang, M.-Y.; Chang, J.-S. Thermochemical conversion of microalgal biomass into biofuels: A review. Bioresour. Technol. 2015, 184, 314-327. [CrossRef] [PubMed]

236. Trivedi, J.; Aila, M.; Bangwal, D.P.; Kaul, S.; Garg, M.O. Algae based biorefinery-How to make sense? Renew. Sustain. Energy Rev. 2015, 47, 295-307. [CrossRef]

237. Dębowski, M.; Zieliński, M. The possibility of using algal cultures in wastewater treatment processes. Water Sewage 2009, 9, 9-12.

238. Bharathiraja, B.; Chakravarthy, M.; Kumar, R.R.; Yogendran, D.; Yuvaraj, D.; Jayamuthunagai, J. Aquatic biomass (algae) as a future feed stock for bio-refineries: A review on cultivation, processing and products. Renew. Sustain. Energy Rev. 2015, 47, 634-653. [CrossRef]

239. Ullah, K.; Ahmad, M.; Sofia Sharma, V.K.; Lu, P.; Harvey, A.; Zafar, M. Assessing the potential of algal biomass opportunities for bioenergy industry: A review. Fuel 2015, 143, 414-423. [CrossRef]

240. Sambusiti, C.; Bellucci, M.; Zabaniotou, A.; Beneduce, L.; Monlau, F. Algae as promising feedstocks for fermentative biohydrogen production according to a biorefinery approach: A comprehensive review. Renew. Sustain. Energy Rev. 2015, 44, 20-36. [CrossRef]

241. Schenk, P.M.; Thomas-Hall, S.R.; Stephens, E.; Marx, U.C.; Mussgnug, J.H. Second generation biofuels: High-efficiency microalgae for biodiesel production. Bioenergy Res. 2008, 1, 20-43. [CrossRef]

242. Raheem, A.; Wan Azlina, W.A.K.G.; Taufiq Yap, Y.H.; Danquah, M.K.; Harun, R. Thermochemical conversion of microalgal biomass for biofuel production. Renew. Sustain. Energy Rev. 2015, 49, 990-999. [CrossRef]

243. Tredici, M.R.; Bassi, N.; Prussi, M.; Biondi, N.; Rodolfi, L.; Chini Zittelli, G.; Sampietro, G. Energy balance of algal biomass production in a 1-ha "Green Wall Panel" plant: How to produce algal biomass in a closed reactor achieving a high Net Energy Ratio. Appl. Energy 2015, 154, 1103-1111. [CrossRef]

244. Maxwell, D.P.; Falk, S.; Trick, C.G.; Huner, N.P.A. Growth at low temperature mimics high-light acclimation in Chlorella vulgaris. Plant Physiol. 1994, 105, 535-543. [CrossRef] [PubMed]

245. Raslavicius, L.; Semenov, V.G.; Chernova, N.I.; Kersys, A.; Kopeyka, A.K. Producing transportation fuels from algae: In search of synergy. Renew. Sustain. Energy Rev. 2014, 40, 133-142. [CrossRef]

246. Huber, G.W.; Iborra, S.; Corma, A. Synthesis of transportation fuels from biomass: Chemistry, catalysts, and engineering. Chem. Rev. 2006, 106, 4044-4098. [CrossRef]

247. Oswald, W.J. Ponds in the twenty-first century. Water Sci. Technol. 1995, 31, 1-8. [CrossRef]

248. Grobbelaar, J.U. Physiological and technological considerations for optimising mass algal cultures. J. Appl. Phycol. 2000, 12, 201-206. [CrossRef] 
249. Mùnoz, R.; Kollner, C.; Guieysse, B.; Mattiasson, B. Photosynthetically oxygenated salicylate biodegradation in a continuous stirred tank photobioreactor. Biotechnol. Bioeng. 2004, 87, 797-803. [CrossRef]

250. Oswald, W.J. My sixty years in applied algology. J. Appl. Phycol. 2003, 15, 99-106. [CrossRef]

251. Javed, F.; Aslam, M.; Rashid, N.; Shamair, Z.; Khan, A.L.; Yasin, M.; Fazal, T.; Hafeez, A.; Rehman, F.; Rehman, M.S.U.; et al. Microalgae-based biofuels, resource recovery and wastewater treatment: A pathway towards sustainable biorefinery. Fuel 2019, 255, 115826. [CrossRef]

252. van Harmelen, T.; Oonk, H. Microalgae Biofixation Processes: Applications and Potential Contributions to Greenhouse Gas Mitigation Options; International Network on Biofixation of CO2 and Greenhouse Gas Abatement with Microalgae: Apeldoom, The Netherlands, 2006.

253. Wang, B.; Li, Y.; Wu, N.; Lan, C. $\mathrm{CO}_{2}$ bio-mitigation using microalgae. Appl. Microbiol. Biotechnol. 2008, 79, 707-718. [CrossRef]

254. Molazadeh, M.; Ahmadzadeh, H.; Pourianfar, H.R.; Lyon, S.; Rampelotto, P.H. The Use of Microalgae for Coupling Wastewater Treatment with $\mathrm{CO}_{2}$ Biofixation. Front. Bioeng. Biotechnol. 2019, 7, 42. [CrossRef] [PubMed]

255. Lundquist, T.J. Production of algae in conjunction with wastewater treatment. In NREL-AFOSR Workshop on Algal Oil for Jet Fuel Production; Arlington, VA, USA, 2008; Available online: https://www.researchgate.net/profile/John_Benemann2/publication/229039925_Overview_Algae_oil_to_ biofuels/links/54171cbf0cf2218008bed0aa/Overview-Algae-oil-to-biofuels.pdf (accessed on 8 August 2020).

256. Chiu, S.-Y.; Kao, C.-Y.; Tsai, M.-T.; Ong, S.-C.; Chen, C.-H.; Lin, C.-S. Lipid accumulation and $\mathrm{CO}_{2}$ utilization of Nanochloropsis oculata in response to $\mathrm{CO}_{2}$ aeration. Bioresour. Technol. 2009, 100, 833-841. [CrossRef] [PubMed]

257. Beachama, T.A.; Mora Maciaa, V.; Rooks, P.; White, D.A.; Ali, S.T. Altered lipid accumulation in Nannochloropsis salina CCAP849/ 3 following EMS and UV induced mutagenesis. Biotech. Rep. 2015, 7, 87-94. [CrossRef] [PubMed]

258. Noraini, M.Y.; Ong, H.C.; Badrul, M.J.; Chong, W.T. A review on potential enzymatic reaction for biofuel production from algae. Renew. Sustain. Energy Rev. 2014, 39, 24-34. [CrossRef]

259. Dębowski, M.; Zieliński, M.; Dudek, M.; Grala, A. Acquisition feasibility and methane fermentation effectiveness of biomass of microalgae occurring in eutrophicated aquifers on the example of The Vistula Lagoon. Int. J. Green Energy 2016, 13, 395-407. [CrossRef]

260. Dębowski, M.; Zieliński, M.; Kisielewska, M.; Krzemieniewski, M. Efficiency of methane fermentation of waste microalgae biomass (WMAB) collected in processes of reclamation of eutrophicated water reservoirs. Environ. Earth Sci. 2016, 75, 525. [CrossRef]

261. Slade, R.; Bauen, A. Micro-algae cultivation for biofuels: Cost, energy balance, environmental impacts and future prospects. Biomass Bioenergy 2013, 53, 29-38. [CrossRef]

262. Dębowski, M. The Use of Algae Biomass as a Substrate in the Methane Fermentation Process; UWM: Olsztyn, Poland, 2013.

263. Guo, L. Doing battle with the green monster of Taihu Lake. Science 2007, 317, 1166. [CrossRef]

264. Zhong, W.; Zhang, Z.; Luo, Y.; Qiao, W.; Xiao, M.; Zhang, M. Biogas productivity by co-digesting Taihu blue algae with corn straw as an external carbon source State Key. Bioresour. Technol. 2012, 114, 281-286. [CrossRef]

265. Qin, B. Lake eutrophication: Control countermeasures and recycling exploitation. Ecol. Eng. 2009, 35, 1569-1573. [CrossRef]

266. Dębowski, M.; Grala, A.; Zieliński, M.; Dudek, M. Efficiency of the methane fermentation process of macroalgae biomass originating from puck bay. Arch. Environ. Prot. 2012, 38, 99-107.

267. Dębowski, M.; Zieliński, M.; Rokicka, M.; Kupczyk, K. The possibility of using macroalgae biomass from natural reservoirs as a substrate in the methane fermentation process. Int. J. Green Energy 2015, 12, 970-977. [CrossRef]

268. Dębowski, M.; Zieliński, M.; Kupczyk, K.; Rokicka, M.; Hajduk, A. Effect of taxonomic diversification of microalgae harvested from eutrophicated reservoirs on the chemical composition of biomass and effectiveness of methane fermentation. Environ. Prog. Sustain. Energy 2015, 34, 858-865. [CrossRef]

269. AquaFUELs. Report on Biology and Biotechnology of Algae with Indication of Criteria for Strain Selection. 2011. Available online: http://www.aquafuels.eu/deliverables.html (accessed on 8 August 2020). 
270. Ryan, D.; Jennifer, M.; Christopher, K.; Nicholas, G.; Eric, T. Process Design and Economics for the Production of Algal Biomass: Algal Biomass Production in Open Pond Systems and Processing Through Dewatering for Downstream Conversion; Technical Report NREL/TP-5100-64772; National Renewable Energy Laboratory: Golden, CO, USA, 2016; pp. 1-119.

271. Gouveia, L. Microalgae as a Feedstock for Biofuels; Springer: Berlin/Heidelberg, Germany; Dordrecht, The Netherlands; London, UK; New York, NY, USA, 2011.

272. Mustapa, N.S.; Abu Mansor, M.S.; Serri, N.A. Design and development of centred-light photobioreactor for microalgae cultivation system. IOP Conf. Ser. Mater. Sci. Eng. 2020, 716, 012009. [CrossRef]

273. Rebolledo-Oyarce, J.; Mejía-López, J.; García, G.; Rodríguez-Córdova, L.; Sáez-Navarrete, C. Novel photobioreactor design for the culture of Dunaliella tertiolecta-Impact of color in the growth of microalgae. Bioresour. Technol. 2019, 289, 121645. [CrossRef] [PubMed]

274. Ma, Y.; Wang, Z.; Zhu, M.; Yu, C.; Cao, Y.; Zhang, D.; Zhou, G. Increased lipid productivity and TAG content in Nannochloropsis by heavy-ion irradiation mutagenesis. Bioresour. Technol. 2013, 136, 360-367. [CrossRef] [PubMed]

275. Lill, J.-O.; Salovius-Lauren, S.; Harju, L.; Rajander, J.; Saarela, K.-E.; Lindroos, A. Temporal changes in elemental composition in decomposing filamentous algae (Cladophora glomerata and Pilayella littoralis) determined with PIXE and PIGE. Sci. Total. Environ. 2012, 414, 646-652. [CrossRef]

276. Ziolkowska, J.R.; Simon, L. Recent developments and prospects for algae-based fuels in the US. Renew. Sustain. Energy Rev. 2014, 29, 847-853. [CrossRef]

277. Singh, A.; Nigam, P.S.; Murphy, J.D. Renewable fuels from algae: An answer to debatable land based fuels. Bioresour. Technol. 2011, 102, 10-16. [CrossRef]

Publisher's Note: MDPI stays neutral with regard to jurisdictional claims in published maps and institutional affiliations.

(C) 2020 by the authors. Licensee MDPI, Basel, Switzerland. This article is an open access article distributed under the terms and conditions of the Creative Commons Attribution (CC BY) license (http://creativecommons.org/licenses/by/4.0/). 